School of Finance

University of St.Gallen

LIQUIDITY CONSTRAINTS, WEALTH TRANSFERS AND HOME OWNERSHIP

KRISTIAN BLICKLE

MARTIN BROWN

Working PAPers on Finance No. 2016/18

SWISS INSTITUTE OF BANKING AND FINANCE (S/BF - HSG)

SEPTEMBER 2016 


\title{
Liquidity Constraints, Wealth Transfers and Home Ownership
}

\author{
Kristian Blickle* and Martin Brown**
}

\section{September 2016}

\begin{abstract}
We study the impact of liquidity constraints on home ownership by comparing the tenure and housing choice of households who receive intra-family wealth transfers to those that do not. Our analysis is based on household-level panel data providing annual information on household characteristics, wealth transfers, tenure status as well as changes in the size and quality of housing. Our treatment effect estimates suggest that wealth transfers increase the propensity of households to transition to ownership by 15 to 20 percentage points. By contrast, wealth transfers do not increase the likelihood that existing homeowners "trade-up" to larger homes in better locations.
\end{abstract}

Keywords: $\quad$ Liquidity Constraints, Tenure Choice, Wealth Transfers, Macroprudential Policy

JEL Codes: D14, D31, D91, G18

* Kristian Blickle: University of St. Gallen, kristian.blickle@ unisg.ch ** Martin Brown: University of St. Gallen, martin.brown@ unisg.ch We gratefully acknowledge comments by: Zeno Adams, Giorgia Barboni, Robert DeYoung, Mariacristina De Nardi, Christian Ehmann, Piet Eichholtz, Roland Füss, Andreas Fuster, Xavier Freixas, Emilia Garcia-Appendini, Michael Haliassos, Tullio Jappelli, Michael Lechner, David Ling, Steven Ongena, Isabel Schnabel, Thomas Spycher. We further acknowledge comments from seminar participants at the University of St. Gallen and Universita della Svizerra Italiana as well as participants at the following conferences: Modena Netspar Workshop 2015, Central Bank of Ireland Conference on Macroprudential Policy, Young Swiss Economists Meeting 2016, Swiss Society of Economics and Statistics 2016, European Economic Association meetings 2016. This paper has previously been circulated as "Borrowing Constraints and Home Ownership" 


\section{Introduction}

Economic theory stipulates that permanent income and preferences govern a household's consumption of durable and non-durable goods in a world of frictionless credit markets (Deaton, 1992). However, if credit markets are imperfect, a household's consumption plan may be limited by currently available income and wealth. Home ownership in particular is affected by such liquidity constraints. Limitations on loan-to-value ratios (LTV) imply that, in order to obtain a residential mortgage, a household must have accumulated sufficient wealth to make an initial down-payment. Thus, conditional on permanent income and preferences, households which receive wealth transfers early on in life, will transition to home ownership at a younger age. ${ }^{1}$

In this paper we examine the impact of wealth transfers on home ownership using household-level panel data from Switzerland. Our sample includes 4,958 households, for an average of 7 years each, between 2002 and 2012. We first study 2,615 households that do not own a home when first observed. We examine the propensity of these households to transition to ownership while in our sample. In addition, we study 2,343 existing homeowners and examine whether they "trade-up",i.e. move to larger homes in better locations. We relate changes in tenure status and housing choices to information on wealth transfers received by the household during the observation period. We control for differences in preferences and permanent income by matching households on an extensive set of socio-economic indicators, including measures of the economic background of a respondent's parents. We control for differences in housing affordability by matching our panel data with regional information on price-to-rent ratios. To account for unobserved variation in

\footnotetext{
${ }^{1}$ The same reasoning applies of course to households which receive a larger share of their lifetime human capital income early on in life.
} 
preferences, permanent income and housing affordability we instrument the timing of wealth transfers with deaths within the closer family in an additional analysis.

Our results suggest that receiving a wealth transfer is associated with a 15- 20 percentage point higher propensity to transition to ownership among initial renters. The magnitude of this effect is remarkable, given that $22 \%$ of the households in our sample transfer from renter to home ownership during the observation period. The relationship between wealth transfers and home ownership is particularly strong for younger households, who are more likely to be borrowing constrained.

Our IV estimates suggest that exogenous wealth transfers, arriving as the result of intra-family deaths, increase the propensity to transition to ownership by 50 percentage points. This local average treatment effect is more than twice as large as our estimates for the average treatment effect on the treated. In the context of our investigation, this increased effect is in line with our predictions. The complier population in our IV analysis consists of households with a high expected permanent income and a possibly stronger preference for home ownership.

We find no evidence that households, which already own a home when first observed, transition to larger homes or homes in better neighborhoods. This result reflects two key features of the housing market in several European countries. Countries such as Germany (or Switzerland) are characterized by low rates of home ownership and a comprehensive market for rental properties ${ }^{2}$. This implies that households, which do not have the wealth required to buy their preferred home, may be able to rent that home instead of buying a smaller home in a less attractive area.

The impact of liquidity on home ownership has recently received increased attention in light of macro-prudential policies designed to reduce systemic risk in the banking sector. In the aftermath

\footnotetext{
${ }^{2}$ http://qz.com/167887/germany-has-one-of-the-worlds-lowest-homeownership-rates/
} 
of the 2007-2009 financial crisis, regulators in Spain, Norway, Sweden, Hong-Kong and many other countries have introduced policies that tighten borrowing constraints in the residential mortgage market (de Lis et al., 2013; Duca et al., 2010, Hong Kong Monetary Authority, 2011). In Ireland, the introduction of these macro-prudential policies have been accompanied by concerns that especially younger households may find it more difficult to enter the housing market. ${ }^{3}$

Switzerland provides an interesting economic environment to study the effect of wealth constraints on home ownership. First, while Swiss home ownership rates have traditionally been among the lowest in Europe, the home ownership rate has risen steadily over the past two decades. Between 1990 and 2014 ownership rates grew by 19 percent from $31.3 \%$ to $37.4 \%{ }^{4}$. Second, over the past decade Switzerland has witnessed a strong appreciation of house prices combined with a fast increase in mortgage lending. Between 2000-2014 the volume of outstanding mortgages doubled from 4443 billion CHF to 896 billion CHF, and now stands at $140 \%$ of GDP. ${ }^{5}$ Fearing that a decrease in house prices may negatively impact overall macroeconomic stability, Swiss regulators enacted macro prudential policies which increased down payment requirements and shortened repayment periods in the residential mortgage market. ${ }^{6}$ As in other countries mentioned above, there are concerns that these policies may exacerbate the effect of liquidity constraints on home ownership. ${ }^{7}$

Our analysis makes two main contributions to the empirical literature on liquidity constraints and housing choice. First, by employing household-level panel data, which includes detailed information on the socioeconomic characteristics and parental background of households, we can

\footnotetext{
${ }^{3}$ http://www.irishtimes.com/business/economy/noonan-wants-review-of-first-time-mortgage-cap-1.2355909

${ }^{4}$ http://www.bfs.admin.ch/bfs/portal/de/index/themen/09/03/blank/key/bewohnertypen/nach_region.html Or see: Eurostat. (February 2015). Distribution of population by tenure status, type of household and income group $51.10 \mathrm{CHF}=1$ Euro in June 2016

${ }^{6} \mathrm{http}: / /$ voxeu.org/article/macropru-policy-switzerland

${ }^{7}$ http://www.nzz.ch/finanzen/bitte-eigenkapital-nachschiessen-1.18219751
} 
improve upon the empirical methodology of previous studies. Using a one-time survey from 1991, Guiso and Jappelli (2002) analyze the effect of intergenerational wealth-transfers on home ownership in Italy. ${ }^{8}$ They find that wealth recipients buy larger homes, although they do not buy at a substantially younger age. Our data allows us to extend their approach in several dimensions: First, we are able to observe changes in tenure status and housing choices for the same households over time and relate these changes to the timing of incoming wealth transfers. Second, we are able to control for the occurrence of significant life-cycle events (marriage, child-birth) which may confound the relation between wealth transfers and housing choices. Third, detailed data on the socio-economic origin of all sample households, including the parental background, allows us to control better for variation in expected permanent income and housing preferences. Finally, information on recent deaths within the family provides us with a strong instrument for the “exogenous" timing of wealth transfers.

Our second contribution, lies in the fact that we examine the impact of wealth constraints on home ownership in an economy with tight leverage limits but a comprehensive rental market for residential properties. We thereby provide a reciprocal complement to recent evidence by Kolodziejczyk and Leth-Petersen (2013), for instance. The authors use panel data to analyze the impact of parental wealth on housing consumption behavior in Denmark, a county associated with high home ownership rates. They find no relationship between parental wealth or wealth transfers and home ownership. The authors themselves attribute some of their result to the specifics of the

\footnotetext{
${ }^{8}$ Linneman et al. (1997) make use of the US-based survey of consumer finance (SCF) to look at the impact of borrowing constraints. In their paper, they extend analyses and methodologies previously developed by Linneman and Wachter (1989) to simulate household constraint and confirm that wealth constraints restrict ownership. They estimate the degree to which a household may be considered constrained. Our analysis makes use of observable wealth transfers to differentiate constrained and unconstrained households.
} 
Danish market, where the down payment requirements are lower (and home ownership rates higher) than in German-speaking regions of Europe.

We also attribute the fact that households in our sample do not "trade up" to differences in the market structure. Our research in this regard complements the findings of Engelhardt and Mayer (1998) who study the effect of wealth transfers on housing choices in the U.S. In a sample of households which transition to ownership, they find that households, which receive wealth transfers, make larger down-payments and transition to larger homes than households that do not receive wealth. This is in line with Guiso and Jappelli (2002) who show that Italian households which receive wealth transfers also transition to larger houses. Our findings suggests that the extent to which liquidity constraints impact on tenure choice and housing quality may depend strongly on the development of the local rental market for residential properties. This is arguably more comprehensive in countries which have low home ownership rates.

The remainder of this paper is structured as follows. Section 2 presents a stylized model of borrowing constraints, tenure choice and housing choice from which we derive empirical hypotheses for the impact of wealth transfers on renters and existing homeowners. Section 3 describes our dataset. Section 4 presents our analysis of the effects of wealth transfers on the propensity of households to transition to home ownership. Section 5 examines whether existing homeowners trade up the property market in response to a wealth transfer. Section 6 concludes. 


\section{Liquidity Constraints, Tenure-Status and Housing Choice}

In this section we present a stylized model of household intertemporal choice to clarify under which circumstances wealth transfers may relax liquidity constraints on tenure status and housing choice. Our aim is to illustrate how early arrivals of expected wealth transfers can impact on tenure choice (ownership vs. renting) and housing choice (size and quality of housing) when households face frictions in the residential mortgage market.

\subsection{Home ownership in perfect credit markets}

Consider a household that lives for two periods, $t=1,2$. At the beginning of each period $t$ the household inherits wealth $W_{t}$ and during each period the household earns wage income $Y_{t}$. In each period the households chooses how much housing $H_{t}$ and how many non-durable consumption goods $C_{t}$ to consume. We assume for simplicity that households do not discount future utility. Preferences of each household are thus given by:

$$
U=u\left(H_{1}, C_{1}\right)+u\left(H_{2}, C_{2}\right) \text {, with } u_{H}^{\prime}, u_{C}^{\prime}>0 \text { and } u_{H}^{\prime \prime}, u_{C}^{\prime \prime}<0
$$

In each period $t$ households can choose to rent or buy a house. Assume that houses can be bought or rented in continuous size (or quality) $H_{t}$. The rental cost of housing per unit and period $r$ is constant in each period. The user cost of housing $k_{i}$ depends on the price of purchasing the house, expected price appreciation, depreciation of the house, property taxes and tax deductions for maintenance and mortgage interest payments. Moreover, user costs would include all transaction costs of buying and selling the house at the beginning/end of the period. User costs for the same house may be heterogeneous across households due to variation in tax benefits for home ownership. We assume that user costs do not differ across periods. The costs of a unit of the non-durable consumption good is normalized to 1 . 
Wage income is non-stochastic and is assumed to be identical in both periods for simplicity: $Y_{1}=$ $Y_{2}=\frac{Y}{2}$. Each household receives a total wealth transfer of $=W_{1}+W_{2}$. The timing of the wealth transfer (i.e. whether a major share arrives in $\mathrm{t}=1$ or $\mathrm{t}=2$ ) may, however, differ across households. For simplicity we assume the interest rate to be zero.

We denote $h_{t}$ as the tenure choice in each period which is 1 for homeownership and 0 for renting. With perfect access to the credit markets, the budget constraint of a household can then be written as:

$$
\sum_{t=1,2} H_{t} \cdot\left(h_{t} \cdot k_{i}+\left(1-h_{t}\right) \cdot r\right)+C_{t} \leq W+Y
$$

With perfect credit markets the tenure choice of households (renting vs. buying) in any period would be determined only by the user cost $k_{i}$ as opposed to the rental cost $r$ of housing. All households for which $k_{i} \leq r$ will buy, while all households for which $k_{i}>r$ will rent. Given that we assume that $k_{i}$ and $r$ are constant over time, the optimal tenure choice of the household $h^{*}\left(r, k_{i}\right)$ is the same in each period.

Conditional on tenure choice, the optimal level of housing in each period $H_{t}$ depends on preferences for housing and consumption goods, the (user or rental) cost of housing, and permanent income $W+Y$. In the absence of discounting and a zero interest rate the concavity of the utility function implies that the optimal volume of housing and non-durable consumption is also constant over time. We can therefore denote $H^{*}\left(W+Y, k_{i}, r\right)$ as the optimal number of housing units the household would want to consume in each period.

In summary, with perfect credit market access neither tenure status $h^{*}$ nor the housing choice $H^{*}$ depends on the timing of expected permanent income. Neither the share of wealth transfers in the 
total permanent income $\frac{W}{W+Y}$ nor the timing of wealth transfers $W_{1}, W_{2}$ influence choices. By contrast, unexpected changes to the level of permanent income due to unexpected wealth transfers will affect housing choice $H^{*}$. In our model, an unexpected change in permanent income could also affect tenure choice $h^{*}$ if it affects the user cost of housing $k_{i}$ through the marginal benefit of tax breaks for homeowners (Henderschott and Slemrod, 1983).

\subsection{Housing choice under liquidity constraints}

Households typically do not have perfect access to credit markets. In the residential mortgage market, lenders impose two main constraints on potential borrowers; a leverage constraint (loan to value ratio) and an affordability constraint (payment-to income ratio). As we are interested in the impact of wealth transfers, we abstract from the affordability constraint and focus on tenure and housing choice in the presence of a leverage constraint. ${ }^{9}$

We assume that households do not have access to unsecured credit (consumer credit), which would allow them to bring forward expected future income and wealth to the first period. ${ }^{10}$ The leverage constraint in the mortgage market and the absence of consumer credit implies that tenure status $h$ and housing choice $H$ may depend on the timing of permanent income. In our model, the timing of

\footnotetext{
${ }^{9}$ The leverage constraint has been shown to be by far the more binding restriction, especially in times of low interest rates (Duca and Rosenthal, 1994; Linneman and Wachter, 1989). Fuster and Zafar (2016) find that a household's stated likelihood of transitioning to ownership diminishes with rising LTVs. Using a short US panel, Haurin et al. (1997) show that young households are sensitive to the relative cost of owning vs. renting, but most affected by down payment requirements. Chiuri and Jappelli (2003) also show that lower initial down-payment ratios are associated with higher rates of ownership, especially among younger households. For Switzerland Brown and Guin (2015) observe significant bunching of mortgage contracts at the mandated LTV threshold of $80 \%$, while the typical PTI threshold of $33 \%$ seems to be much less binding.
}

\footnotetext{
${ }^{10}$ Otherwise households could circumvent leverage constraints in the mortgage market by borrowing against future wealth transfers and income in the consumer credit market.
} 
permanent income is determined (i) by the timing of wealth transfers (and wage income) across periods, and (ii) by the share of permanent income which is received through wealth transfers (as these are received before wage income in each period).

Consider those households who would choose to buy a house $\left(h^{*}=1\right)$ under perfect credit market access. These "would-be-homeowners" are households which have a low user cost compared to the rental cost of housing, (i.e. $k_{i} \leq r$ ). Due to the leverage constraint, the volume of housing a household can buy in period $t$ is limited by its accumulated financial wealth at the beginning of each period $A_{t}$. Defining $L T V$ as the maximum loan-to-value ratio and $p_{t}$ as the purchasing price of a unit of housing, the leverage constraint implies:

$$
\begin{aligned}
& p_{t} \cdot H_{t} \cdot(1-L T V) \leq A_{t}, \text { whereby } \\
& A_{1}=W_{1} \\
& A_{2}=W+Y_{1}-H_{1} \cdot\left(h_{1} \cdot k_{i}+\left(1-h_{1}\right) \cdot r\right)-C_{1}
\end{aligned}
$$

Given our simplifying assumptions, "would-be homeowners" would want to consume the same volume of housing and other consumption goods in each period under perfect credit access and would therefore spend an equal amount of their permanent income $(W+Y) / 2$ in both periods. This would imply that $A_{2}=W / 2$. Therefore a would-be homeowner is not constrained by the leverage constraint if

$$
\begin{aligned}
& \text { [3a] } \quad p \cdot H^{*}\left(W+Y, k_{i}\right) \cdot(1-L T V) \leq W_{1}, \\
& \text { [3b] } \quad p \cdot H^{*}\left(W+Y, k_{i}\right) \cdot(1-L T V) \leq W / 2
\end{aligned}
$$

Conditions [3a] and [3b] clarify two potential effects of the leverage constraint: 
- If [3b] holds but [3a] does not: The total wealth transfer is sufficiently high to meet the leverage constraint in both periods. However, the timing of the wealth transfer does not enable the purchase of this house in period 1. Conditional on permanent income $(Y+W)$, preferences for housing, the user cost of housing $k$ and the leverage constraint $L T V$; this situation is more likely to arise for households which derive a significant share of their permanent income from wealth transfers, but only receive these transfers later on in life.

- If [3b] does not hold: The total wealth transfer $W$ is not sufficient to enable the purchase of the preferred house $H^{*}$ over both periods. Conditional on permanent income $(Y+W)$ and preferences for housing. This is likely to be the case for households which receive little or none of their permanent income from wealth transfers. It is also likely to be the case when the user cost of housing $k$ is low (financing costs and depreciation), but purchasing prices $p$ are high (i.e. in times of low interest rates).

Households which are constrained by the LTV restriction have two potential ways to adjust their behavior: Some constrained households may buy a smaller house (or a house in an undesirable area) in period 1 and then trade-up in period 2 (i.e. move to a larger house in a different neighborhood). These are likely to be households with a strong monetary advantage of homeownership vis-a-vis renting (i.e. a very low user cost of housing $r>>k$ ). Moreover these are likely to be households who receive a large share of their permanent income as wealth transfers, but these transfers arrive late in life.Other households will rent a house in period 1 and then transition to ownership in period 2. These are also likely to be households who receive a large share of their permanent income as wealth transfers that arrive late in life. Compared to the above group, 
though, these are households with a weaker preference for homeownership vis-a-vis renting (i.e. a higher user cost of housing). Finally, some households will be forced to rent in both periods.

For completeness, let us now turn to those households who would choose to rent a house $\left(h^{*}=0\right)$ under perfect credit market access. These "would-be renters" are households for which $k_{i}>r$ (i.e. which have a high user cost compared to the rental cost of housing). For these households liquidity constraints may impact on housing choice $H$ but not on tenure choice $h$. In our simple framework, these households would consume the same volume of housing and other consumption goods in both periods under perfect credit market access. In the absence of a consumer credit market they

can only do so if $W_{1}+Y_{1} \geq \frac{W+Y}{2}$. Thus if the first period wealth transfer is low, even renters will have to cut back on the consumption of housing (and non-durable goods) in period 1. This effect is not the focus of this paper.

\subsection{Hypotheses}

Our above model leads us to two main hypotheses regarding wealth transfers, tenure status, and housing choice which will guide our empirical analysis:

Hypothesis 1 (Wealth transfers and tenure status): Conditional on permanent income, preferences for housing, as well as the user cost and rental costs of housing, the receipt of a significant wealth transfer is associated with a higher propensity for renters to transition to homeownership.

Hypothesis 2 (Wealth transfers and housing choice): Conditional on permanent income, preferences for housing, as well as the user and rental costs of housing the receipt of a significant 
wealth transfer is associated with "trading-up". Existing homeowners move to larger dwellings and/or to better locations.

\section{Data}

Our main source of data is the Swiss Household Panel (SHP) ${ }^{11}$. Our sample is comprised of all households which were covered by the SHP for at least 3 years during the period 2002 and $2012 .{ }^{12}$ The sample includes 4,958 households with a total of 39,545 household-year observations. See online Appendix 1 for an overview of the number of households by year of first observation and number of years in sample.

The panel structure of our data allows us to study the relationship between wealth transfers and the change in tenure status/housing choice for the same household over time. Our main analysis is based on a between effects (or cross sectional) approach in which we relate changes in tenure choice and housing choice of each household, over the entire observation period, to the receipt of wealth transfers and changes in household characteristics over that same period. Our reasons for making use of a cross sectional approach are twofold. First, we only observe each household for a small portion of their life-cycle. A cross sectional analysis is suited to studying the differences in tenure and housing choices across households, specific to a point in their respective life-cycles. Second, estimates of year-on-year changes in a panel framework may be influenced by the varying

\footnotetext{
${ }^{11}$ The SHP is based on annual surveys administered by FORS at the University of Lausanne. The first wave of the survey was initiated in 1999 and comprised over 7,700 households that were intended to be representative of Switzerland's diverse demography. In order to counteract the natural attrition inherent to such surveys, new families were added in each year. More than 1,800 households have been observed over the entirety of the survey's runtime. For further details on the survey see http://forscenter.ch/en/our-surveys/swiss-household-panel/ .

${ }^{12}$ Given changes in the construction and definition of key variables, we cannot make use of the survey waves from 1999-2001.
} 
amounts of time it takes a household to respond to changes in wealth. Transitioning to a new home can be quicker for some households than others, often depending on family and region specifics ${ }^{13}$.

To examine the relationship between wealth transfers and tenure status, we study 2,615 households which are initial renters. For this sample, we relate changes in tenure-status to the receipt of wealth transfers that can be observed while households are in the sample. For each household $i$ in each year $t$ the SHP reports the tenure status (i.e. whether the household owns or rents the dwelling in which it lives). Our first dependent variable captures within-household changes in tenure status. For a household which we observe for the first time in year $t=0$ and last time in year $t=T$, we define Homeownership $=1$ if the household was a renter in period $\mathrm{t}=0$ and transitions to ownership by $t=T$. By contrast, Homeownership $=0$ if the household was a renter in period $\mathrm{t}=0$ and still a renter in $t=T$. Summary statistics in Panel A of Table 1 show that $23 \%$ of initial renters transition to homeownership while observed by the survey.

[Table 1 here]

We study the relationship between wealth transfers and housing choices in the complementary sample of 2,343 initial homeowners. For this subsample we examine whether a household moves, and whether it experiences a change in housing size or housing quality. For each household in each year the SHP reports whether the household lives in the same dwelling as last year, as well as indicators of the size and quality of the chosen home. The dummy variable MoveHouse captures

\footnotetext{
${ }^{13}$ In the Online Appendix, we exploit information on year-on-year changes by conducting a cox-hazard analysis. We relate the change in tenure status in year $t$ to wealth transfers (received since first observation in the data). The survival model allows us to better pinpoint whether households are more likely to transition to ownership after they receive a wealth transfer. It ostensibly reflects the fact that our record-keeping for some households may end before we observe the transition to ownership (i.e. right censoring). Its primary disadvantage lies in the fact that it does not account for wealth transfers that are, for whatever reason, recorded after a household transitions to ownership.
} 
whether the household changed its dwelling any time between $t=0$ and $t=T$. Our proxy of house size measures the number of rooms of the home. Our proxy for the quality of the home captures on a scale of 0-3 to what extent the respondents are satisfied with noise, pollution and vandalism conditions in their neighborhood. The variable $\Delta$ HouseSize captures changes in the number of rooms of the dwelling in $t=T$ minus $t=0$. The variable $\Delta$ LocationQuality capture changes in the perceived quality of the location of the dwelling in $t=T$ minus $t=0$. A household is considered to have moved if it reports a location change since the last survey wave. Summary statistics in Panel B of Table 1 show that $23 \%$ of initial homeowners move while observed by the survey. The average size of the dwelling decreases by 0.1 rooms while the perceived location quality remains unchanged.

The explanatory variable in both analyses is an indicator of whether a household receives a wealth transfers. We define a significant wealth transfer as receiving more than 50,000 CHF from family members outside the immediate household as well as from inheritance, bequests and other sources. We choose CHF 50,000 as the threshold for a relevant wealth transfer as this amounts to roughly $10 \%$ of the mean house price $(\mathrm{CHF} 510,000)$ during our sample period. In robustness tests, we check whether our main results are sensitive to this threshold definition. WealthTransfer, therefore, takes on the value of 1 if the household received a significant wealth transfer in any year $0 \leq t \leq T$, and zero otherwise. Summary statistics in Table 1 show that $20 \%$ of initial renters and nearly $30 \%$ of initial owners receive a wealth transfer while observed in the survey.

As suggested by our model, we need to condition tenure and housing choices on (expected) permanent income, household preferences for housing, and the relative costs of buying or renting homes. The SHP provides a broad set of household-level indicators which proxy for expected wealth and income as well as for preferences related to housing and home ownership. Moreover, 
we match households in the SHP by location with data on regional prices and rental costs of houses for all 103 MS regions represented in the survey to obtain indicators of the costs of purchasing or renting a house. Appendix 2 presents definitions and remainder of Table 1 presents summary statistics for all variables employed in our analysis. We discuss our use of these control variables in detail when we present our empirical methodology below.

\section{Wealth Transfers and Tenure Status}

Our analysis in this section is based on the sample of 2,615 households which are initial renters. For this sample, we examine whether changes in tenure-status are related to the receipt of wealth transfers. Figure 1 displays the likelihood of a household transitioning to ownership. We separate households by whether they receive a wealth transfer or not. The receipt of wealth is associated with a significantly higher propensity to transition to ownership across all age groups (using age of primary respondent at first observation). For example, among households younger than 35 , a wealth transfer more than doubles the propensity to transition to homeownership.

[FIGURE 1 here]

\subsection{Identification}

Our first main identification challenge arises from the fact that we are unable to isolate the population of would-be homeowners in a world of perfect credit markets. Any population we employ for our analysis is likely to contain at least some households which would prefer to rent even if they had access to perfect credit markets. However, wealth transfers can only influence the tenure status of would-be homeowners. We are therefore likely to underestimate the average treatment effect on the key population of interest (i.e. would-be homeowners). This identification 
challenge is accentuated by our sample choice. By focusing on households that rent at first observation, we can induce a selection problem. Our sample may be overpopulated with households that prefer renting to buying, especially among the older cohorts. Many households that prefer to own a house may have already bought a home before we observe them for the first time. They may have saved for the down-payment or already received wealth. In line with this concern, Figure 1 shows that the propensity of households to transition to home ownership declines with their age at first observation. Due to sample-selection issues, our estimates cannot be interpreted as average treatment effects on the population of would-be homeowners. Arguably, our estimates are closer to the average effect on would-be homeowners for young rather than older households. In the section below, we therefore examine whether the effects of wealth transfers are heterogeneous across respondent age.

Our second main identification challenge arises from confounding the relationship between wealth transfers and tenure status. We predict that households, which receive early wealth transfers, are more likely to transition to home ownership (conditional on permanent income and preferences for home ownership). It is, however, very likely that households, which receive wealth transfers, have stronger preferences for home ownership. Firstly, households which receive wealth transfers are more likely to come from a wealthier family background. Such households are likely to have higher expected lifetime income and wealth or stronger preferences for home ownership and housing due to childhood experiences ${ }^{14}$. Secondly, households may receive wealth transfers upon life-cycle events, which are associated with stronger preferences for home ownership (e.g. marriage or childbirth).

\footnotetext{
${ }^{14}$ See Aratani (2011) for a discussion of preference transmission. They point out that preference transmission is likely to be strongest in households that we would classify as having high permanent income.
} 
Some pre-death wealth bequests may actually be triggered by household's searching for a new home. This is more likely the case for households, which attach a higher value to home ownership and housing. For the nearly 200 households in our sample, which both transition to ownership and receive a wealth transfer, figure 2 depicts the relative timing of home purchases and wealth transfers. The largest share of households (72\%) buy home in exactly the same year or within two years of receiving a wealth transfer. Some of these wealth transfers are likely to be pre-death bequests triggered by the recipients themselves. Others are likely to be the result of a spurious correlation of wealth transfers and home ownership (e.g. due to life-cycle events such as marriage, children). Figure 2 thus highlights the importance of accounting for confounding relations between wealth transfers and tenure status.

[FIGURE 2 here]

A final issue worth considering is the possibility that a wealth transfer may be unexpected. This would imply a change in expected permanent income rather than in the timing of expected permanent income. Even for households who expect some wealth transfer in the future, the magnitude of the transfer may be larger than anticipated. We mitigate this issue, to a degree, by making use of binary variables. It remains important, however, to be able to account for the likelihood with which a household will receive a substantial wealth transfer.

\subsection{Selection on Observables}

\subsubsection{Methodology}

To account for the confounding role of preferences, permanent income and life-cycle events on wealth transfers and tenure status, we match households on an extensive set of socioeconomic 
characteristics. We label $Y_{1}$ as the potential outcomes for households if they receive a wealth transfer and $Y_{0}$ as the potential outcomes for households if they do not receive a wealth transfer. We assume that the following independence relationship holds. Conditional on the observables $X_{i}$ those households which receive a wealth transfer $(W=1)$ and those who do not $(W=0)$ would have the same potential tenure status and housing choice if both would not have received a wealth transfer.

[4] $\quad E\left[Y_{0} \mid W=1, X_{i}\right]=E\left[Y_{0} \mid W=0, X_{i}\right]$

We can then estimate the average treatment effect on the treated (ATET) as

[5] $\quad E\left[Y_{1} \mid W=1, X_{i}\right]-E\left[Y_{0} \mid W=0, X_{i}\right]$

To account for differences in permanent income, our vector of confounding variables $X_{i}$ includes respondent Education, Age, and current Income. Importantly, given the issues of unexpected wealth discussed above, we also account for expected wealth transfers. We do this by exploiting information on the socioeconomic background of respondents as reported in the SHP. On the one hand, we employ an indicator of the economic activity of the parents when the respondent was a teenager. Hereby, respondents whose parents were self-employed with employees, partners or managers are classified as having Wealthy parents. On the other hand, we account for the number of Sibblings of the respondent, as large wealth transfers are less likely cet. par. for respondents with sibblings.

To account for differences in preferences for home ownership and housing we include in $X_{i}$ an indicator of whether a household is Married (or living together) and capture the Number of Children in the household. We further account for maritial status and children at first observation as well as changes over the observation period for the household. Moreover, we again exploit 
information on the socioeconomic background of respondents: The variable Intact Home captures whether at least one respondent (in a two person household) lived with both parents while growing up. Respondents who grew up in "intact" homes may have a stronger preference for home ownership and higher permanent income ${ }^{15}$. For a large subset of households we also observe information on repayment behavior, willingness to make plans as well as political affiliations. The ability to repay loans, measured by whether the household has fallen into repayment arrears, will factor in a household's mortgage application decision. The variable Planning ability may be associated with the demand for housing through the personal discount factor. The variable Political lean (e.g. if right-leaning where right $=10$ ) may be associated with a preference for housing and homeownership.

To account for differences in the relative costs of owning vs. renting houses we match households by location on the Price/rent ratio. Furthermore, to account for differential tax treatment of home ownership across the Swiss cantons we include canton-fixed effects in our matching exercise. Finally, we account for the year in which a household entered the survey.

We estimate the ATET in equation [5] using three different estimation techniques. Our baseline model is a linear probability model. Given the binary nature of our dependent variable, we additionally estimate a probit model as well as a propensity-score matching model (radius matching).

\subsubsection{Results}

Baseline estimates from a linear probability model are reported in Table 2. The coefficients reported in columns (1) and (2), make use of the full sample. We report only the coefficients of

${ }^{15}$ See Hubers et al. (2016) for a discussion. 
interest as well as the coefficients on age (truncated into categories) for brevity. Longform versions of the regressions can be found in online Appendix 3. Column (1) makes use of our set of basic household characteristics while (2) includes all possible preference controls. We lose some observations in column (2). In columns (3) to (8) we split our sample by age of the primary respondent at first observation, again showing basic and full variable regressions in adjacent columns.

\section{[TABLE 2 here]}

Controlling for basic household characteristics, as in column (1), we find that a wealth transfer increases the propensity of a household to transition to ownership by over 16.8 percentage points (or about 74 percent of the mean). The overall magnitude of the effects is confirmed by the probit regression and exceeded by matching estimates, both shown in Appendix 4. Column (2) suggests that our estimate is unaffected by including additional regressor at the cost of a few observations. Overall, columns (1) and (2) suggest that borrowing constraints substantially influence a household's ability to transition to owner occupied housing.

If we compare younger households to older ones, we see that this effect is strongest in younger households. In the sample of households that are younger than 35 at first observation a wealth transfer increases the propensity to transition to ownership by 27 percentage points ( 82 percent of the mean for this subsample). By comparison, in the subsample of households who are older than 50 the estimated effect is a mere 8 percentage points (but still 70 percent of the subsample mean). Our findings are in line with Chiuri and Jappelli (2003) who find that borrowing constraints affect young households more severely. They are, however, also consistent with our conjecture that our full-estimates may be biased downwards by sample selection: Especially among older households 
our sample of initial renters may comprise a large share of households which prefer to rent rather than own a house.

In the online appendix we perform a number of robustness tests. In Appendix 5 we vary the threshold of what defines a wealth transfer, leaving all other aspects of the regression unchanged. Transfers between 10,000 and 50,000 $\mathrm{CHF}$ have a much smaller and insignificant effect. Conversely, larger transfers do not increase the propensity of a household to transition to ownership beyond what we find in our original regression. In Appendix 6 we vary the threshold of what constitutes a wealth transfer according to the price level of the region in which the respondent's live. If we require a wealth transfer to constitute $10 \%$ of the local house price in an MS region, for example, our results are qualitatively unchanged. Finally, in Appendix 7 we show the results of a survival analysis which relates annual wealth transfers to subsequent changes in tenure status. We use years in sample as our time dimension. Our full-sample estimates suggest that once a household receives wealth, it is three times as likely to transition to ownership in the following years.

\subsection{Instrumental Variable Analysis}

\section{$\underline{4.3 .1 \text { Methodology }}$}

Acknowledging that the conditional independence assumption in equation [4] may not hold perfectly, we additionally perform an instrumental variable analysis. We instrument the receipt of a wealth transfer $W_{i}$ with information about the death of relatives of the household as reported in the SHP.

In each year, each household is asked whether a close relative has died. For a household which we observe for the first time in year $t=0$ and last time in year $t=T$ we define FamilyDeath $=1$ if 
a close relative died in any year $0 \leq t \leq T$, and zero otherwise.Arguably, the death of a close relative is likely to increase the propensity of a household to receive a wealth transfer. Indeed, in our sample the tetrachoric correlation of FamilyDeath and WealthTransfer is 0.28 and highly significant. The death of a relative is likely to trigger a wealth transfer especially for those households which (i) have wealthy relatives and (ii) those relatives were not inclined to make a pre-death bequest. It must therefore be noted that the complier population in our instrumental variable analysis, while relevant population for the purpose of our study, is also a special one. In particular, we are estimating a local average treatment effect (LATE) among households who expect a high permanent income. These households may have a strong preference for housing and home ownership, which has been cultivated through exposure to wealthy home owning relatives. We consequently expect a larger effect of the treatment than derived in our matching/OLS estimates, which are based on the full sample of initial renters. Appendix 8 compares key socioeconomic characteristics for households who inherit at least 50,000 CHF in column (1) to households who, despite a death in the family, do not in column (2). While it is of course impossible to show the exact complier population, the table presents an overview of the differences between the types of households who stand to inherit and those that do not. We show that families who inherit exhibit signs associated with a higher permanent income (i.e. wealthy parents, education and current income). These are also the only dimensions (except for marriage) across which the sub-groups differ in a statistically meaningful way.

A good instrument must fulfill several conditions; it should affect the treatment, be random across the sample, and fulfill the exclusion restriction. Given the correlations, discussed above, as well as general intuition; death of a close relative is arguably a strong predictor for the timing of a wealth 
transfer. Moreover, conditional on a household respondent's age, the occurrence of FamilyDeath should be random across our population ${ }^{16}$.

The argument that our instrument also meets the exclusion restriction is slightly more difficult for three reasons. Firstly, the death of a close relative may not only lead to financial wealth transfers, which we capture by $W_{i}$, but may also lead to the direct inheritance of a house. Even if this inheritance is expected, frictions in the real-estate market may induce the household to occupy an inherited house, rather than sell it off and continue to rent. Secondly, the wealth transfer induced by the death of a relative may be unexpected and thus constitute a change in the level of permanent income, as discussed in detail above. Third, the death of a close relative could possibly constitute a life-cycle event which triggers changes in household preferences for housing.

In a regression that includes our control variables and our regressor, wealth, we find no evidence that a death in the family increases the propensity with which a household transitions to ownership. Moreover, the baseline coefficients on wealth transfers remain unchanged in these regressions. While this should only be seen as indicative evidence, it does seem that our instrument itself does not affect our outcome in the face of our controls and treatment. In order to mitigate the above concerns, we therefore include our vector of household-level control variables $X_{i}$ in our instrumental variable estimation. We thus assume the following conditional exclusion restriction holds:

$$
Y(\text { FamilyDeath }=1, W, X)=Y(\text { FamilyDeath }=0, W, X)
$$

\footnotetext{
${ }^{16}$ This holds especially in Switzerland where, given mandatory health insurance, access to healthcare is not determined by wealth.
} 
where $\mathrm{Y}$ refers to a household's transition to ownership, $\mathrm{X}$ is a vector of all confounding variables and $W=0,1$.

Given that our endogenous treatment variable is binary, we estimate the IV-model employing a "zero-stage" regression prior to the ordinary two stage least square regressions. Prior estimation of instruments has grown in popularity in recent years; see Dahl \& Lochner (2012), Nichols (2007), or Egger \& Pfaffermayr (2003) for examples or discussions of this. In this paper, we follow procedures suggested by Wooldridge (2002): we use a probit regression to estimate the propensity of a household to receive wealth, using our excluded instruments and included instruments as regressors. We predict the probability of receiving wealth for each household in our sample, using the specified probit model and subsequently use this prediction as a single excluded instrument in a two-staged IV regression. This procedure increases the precision and efficiency of the IV estimator.

\section{$\underline{4.3 .2 \text { Results }}$}

Results of the IV estimation are presented in Table 3. Column (1), uses only death of a relative as an instrument. Column (2) includes an interaction term between death of a relative and whether a household had wealthy parents. The Kleibergen-Paap F- and rk-statistics, reported at the end of the table, are calculated for the excluded instruments themselves (i.e. without zero-stage estimation).

[Table 3 about here] 
We show that a household's propensity to transition, given an instrumented receipt of wealth, increases by $50 \%$-pts. The validity of the instrument is supported by the Kleinberg-Papp statistics. For the specification in column (2), we are able to confirm that our regression is not over-identified. The test is not possible in column (1), given that we use only one instrument. The size of the coefficient on instrumented wealth, which expresses the probability that a household may receive wealth, is larger than the coefficient on actual wealth transfers. Households with high expected permanent income, of which inherited wealth is a substantial portion, are highly likely to transition to ownership upon receiving exogenous wealth.

\section{Wealth transfers and "trading up"}

In this section we study the relationship between wealth transfers and changes in housing choice for the sample of 2'343 initial homeowners. Specifically, we examine whether a household moves, or whether it experiences a change in housing size and location quality in response to the receipt of wealth.

Figure 3 displays the propensity of a household to move, changes in the number of rooms of the dwelling, and changes in the perceived quality of the location. We again separate the sample by whether respondents receive wealth or not. The graph is split by respondent's age at first observation. We find no clear pattern that households who receive wealth actually "trade up" during our observation period.

[FIGURE 3 here] 


\subsection{Identification and Methodology}

Our main identification challenge in this section comes from confounding relations between wealth transfers and housing choice. We predict that, conditional on permanent income as well as preferences for home ownership and housing, households which receive early wealth transfers are more likely to trade up. As discussed in detail above, this should be particularly likely for households who bought a home that was smaller than the ideal, driven by a strong preference for ownership over renting $(\mathrm{k}<<\mathrm{r})$. We are plagued by many of the same identification challenges discussed in section 4 above. We must again be able to account for household preferences as well as life-cycle events that induce desires for a larger home and intra-family transfers (e.g. birth of a child or marriage). First, we match treated households (those which receive wealth transfers) and non-treated households on an extensive set of observable characteristics. In a second step, we again instrument wealth transfers with deaths in the close family.

In contrast to our analysis of tenure status our analysis of "trading-up" is hardly affected by sample selection. The reason is that we conduct our analysis on a subset of households which are already homeowners. Thus, we can safely assume that our results are based on a subset of households which would choose to buy a house if liquidity constraints were not binding.

\subsection{Results}

We find no evidence for an effect of wealth transfers on the housing choice of households that already own a home. The Table 4 results shows that the receipt of a wealth transfer does not increase the propensity to move (columns 1-2). A wealth transfer also has no sizeable or significant 
effect on the change in the number of rooms of the dwelling (columns 3-4) or the change in neighborhood satisfaction (columns 5-6).

Instrumentation of wealth transfers with deaths of family members does not alter our results (see Table 5). Again, the estimated coefficient for wealth transfer remains small and insignificant. It is worth noting that in Table 5 the instrument is not a strong as in the analysis of tenure choice, reported in Table 3. This is despite the fact that nearly $30 \%$ of households receive wealth. A possible explanation may lie in the fact that some wealthy households, having already received a pre death bequest to buy their home, do not change housing consumption in response to an inheritance in this subsample.

[Table 4 here]

[Table 5 here]

Our finding that wealth transfers are not associated with trading up of existing homeowners is novel and stands in contrast to existing literature for the U.S. (Engelhardt and Mayer, 1998) and Italy (Guiso and Jappelli, 2002). As suggested by our theoretical model, households which prefer to own, rather than rent a house, can react in two different ways to liquidity constraints. On the one hand, they can initially buy a "suboptimal" house and then trade up. On the other hand they can initially rent a house and later transition to homeownership. In our model we assumed that households can freely choose between renting and owning any property. Thus the decision to initially rent or own is driven by preferences for home ownership. In reality, however, the decision 
to rent or buy will also be influenced by the development of the rental market for residential properties.

In Switzerland, the residential market is characterized by a wide variety of available rental properties. This implies that households, which cannot buy high-quality homes due to liquidity constraints, could well be able to rent the same type of property. We conjecture that the welldeveloped rental market may explain why wealth transfers are associated with transitions to ownership but not with trading up of homeowners in our sample: Liquidity constrained households who cannot buy their preferred home are more likely to rent that home rather than buy a suboptimal one. In other countries, with more pronounced home ownership rates, certain types of properties in good regions may only be available to households who buy. 


\section{Conclusion}

In this paper, we analyze the effects of liquidity constraints on tenure status and housing choice by comparing households which receive wealth transfers to those that do not. Our analysis is based on household-level panel data from Switzerland which includes detailed information on the socioeconomic background of households, including the economic status of parents.

We document a substantial effect of wealth transfers on the propensity of households to transition from renters to homeowners. Our full sample results suggest that a wealth transfer increases the propensity of a household to transition to ownership by 17 percentage points ( $74 \% \%$ of the sample mean).We find a particularly strong effect of wealth transfers on homeownership for younger households, suggesting that households which have had less time to accumulate wealth, are particularly impacted by liquidity constraints.

We find no evidence that wealth transfers induce existing homeowners to trade up in the property market. That is, homeowners which receive a wealth transfer are not more likely to move to larger homes in more preferred locations. This finding is novel and is line with the observation that that the rental market for residential properties of high quality is well developed in Switzerland. In such a market liquidity constrained households can rent their preferred home (and later transition to ownership) rather than buy a less preferred home (and later trade up).

Our findings point to potential side-effects of recent macro-prudential regulations, designed to ensure the stability of the financial sector. Increased LTV-thresholds and limits on the types of equity that can be used to make down payments (e.g. limits on the use of pension savings) do not impact all households in the same way. Households without access to intergenerational wealth transfers will be disproportionally affected by the tightening of leverage constraints in the mortgage 
market. Thus while arguably promoting financial stability, macroprudential regulation of the mortgage market may undermine public policy to foster homeownership -among younger and economically disadvantaged households. Given the various benefits believed to be associated with home ownership (Campbell et al. 2011; HUD, 1995; Ioannides and Zabel, 2003) this tradeoff deserves attention. 


\section{References}

Aratani, Y. (2011). Socio-demographic Variations of Homeowners and Differential Effects of Parental Homeownership on Offspring's Housing Tenure. Housing Studies, 26(5), 723-746. http://doi.org/10.1080/02673037.2011.581912

Boehm, T., \& Schlottmann, A. M. (1999). Does Home Ownership by Parents Have an Economic Impact on their Children? Journal of Housing Economics, 217-232.

Brown, M. \& Guin, B., (2015). The Exposure of Mortgage Borrowers to Interest Rate Risk and House Price Risk - Evidence from Swiss Loan Application Data. Swis Journal of Economics and Statistics, 3-37.

Campbell, J., Giglio, S., \& Pathak, P. (2011). Forced Sales and House Prices. American Economic Review, 2108-31.

Chiuri, M., \& Jappelli, T. (2003). Financial market imperfections and home ownership: A comparative study. European Economic Review, 47 (5), 857-875.

Dahl, G. B., \& Lochner, L. (2012). The Impact of Family Income on Child Achievement. American Economic Review, 102(5), 1927-1956.

de Lis, S., Chaibi, S., Izquierdo, J., Lores, F., Rubio, A., \& Zurita, J. (2013). Some international trends in the regulation of mortgage markets: Implications for Spain. BBVA Research - Working paper series, 13/17.

Deaton, A. (1992). Understanding Consumption. Oxford: Oxford University Press.

Duca, J., \& Rosenthal, S. (1994). Borrowing constraints and access to owner-occupied housing. Regional Science and Urban Economics, 24(3), 301-322.

Duca, J., Muellbauer, J., \& Murphy, A. (2010). Housing markets and the financial crisis of 20072009: Lessons for the future. Journal of Financial Stability, 6, 203-217.

Egger, P., \& Pfaffermayr, M. (2003). The Counterfactual to Investing Abroad: An Endogenous Treatment Approach of Foreign Affiliate Activity. University of Innsbruck: Working Paper Series.

Engelhardt, G., \& Mayer, C. (1998). Intergenerational Transfers, Borrowing Constraints, and Saving Behavior: Evidence from the Housing Market. Journal of Urban Economics, 44(1), 135157.

Fuster, A., \& Zafar, B. (2016). To Buy or Not to Buy: Consumer Constraints in the Housing Market. American Economic Review, 106(5), 636-640. http://doi.org/10.1257/aer.p20161086

Guiso, L., \& Jappelli, T. (2002). Transfers, Borrowing Constraints and the Timing of Homeownership. Journal of Money, Credit and Banking, 34(2), 315-339. 
Haurin, D., Hendershott, P., \& Wachter, S. (1997). Borrowing Constraints and the Tenure Choice of Young Households. Journal of Housing Research, 8(2).

Hong Kong Monetary Authority. (2011). Loan-to-value ratio as a macroprudential tool - Hong Kong SAR's experience and cross-country evidence. Hong Kong: BIS Papers No 57.

Hubers, C., Dewilde, C., \& De Graaf, P. (2016). Implications of parental divorce for the homeownership of their adult children. Retrieved from www.tilburguniversity.edu/howcome

Ioannides, Y., \& Zabel, J. (2003). Neighbourhood Effects and Housing Demand. Journal of Applied Econometrics, 563-584.

Linneman, P., \& Wachter, S. (1989). The impacts of borrowing constraints on homeownership. Real Estate Economics 17 (4), 389-402.

Linneman, P., Megbolugbe, I. F., Wachter, S. M., \& Cho, M. (1997). Do Borrowing Constraints Change U.S. Homeownership Rates? Journal of Housing Economics, 6(4), 318-333. http://doi.org/10.1006/jhec.1997.0218

Nichols, A. (2007). Causal inference with observational data. The Stata Journal, 7(4), 507-541.

U.S. Department of Housing and Urban Development (HUD). (1995). Urban Policy Brief. U.S. Department of Housing and Urban Development.

Wooldridge, J. M. (2002). Econometric Analysis of Cross Section and Panel Data. Cambridge, Massachusetts: The MIT Press. 
Figure 1. Wealth Transfers and transition to Home Ownership

For initial renters, this figure depicts the propensity of a household to transition to Home Ownership, split by whether it receives a Wealth Transfer. Numbers above each bar indicate sample size. We separate households by age at first observation.

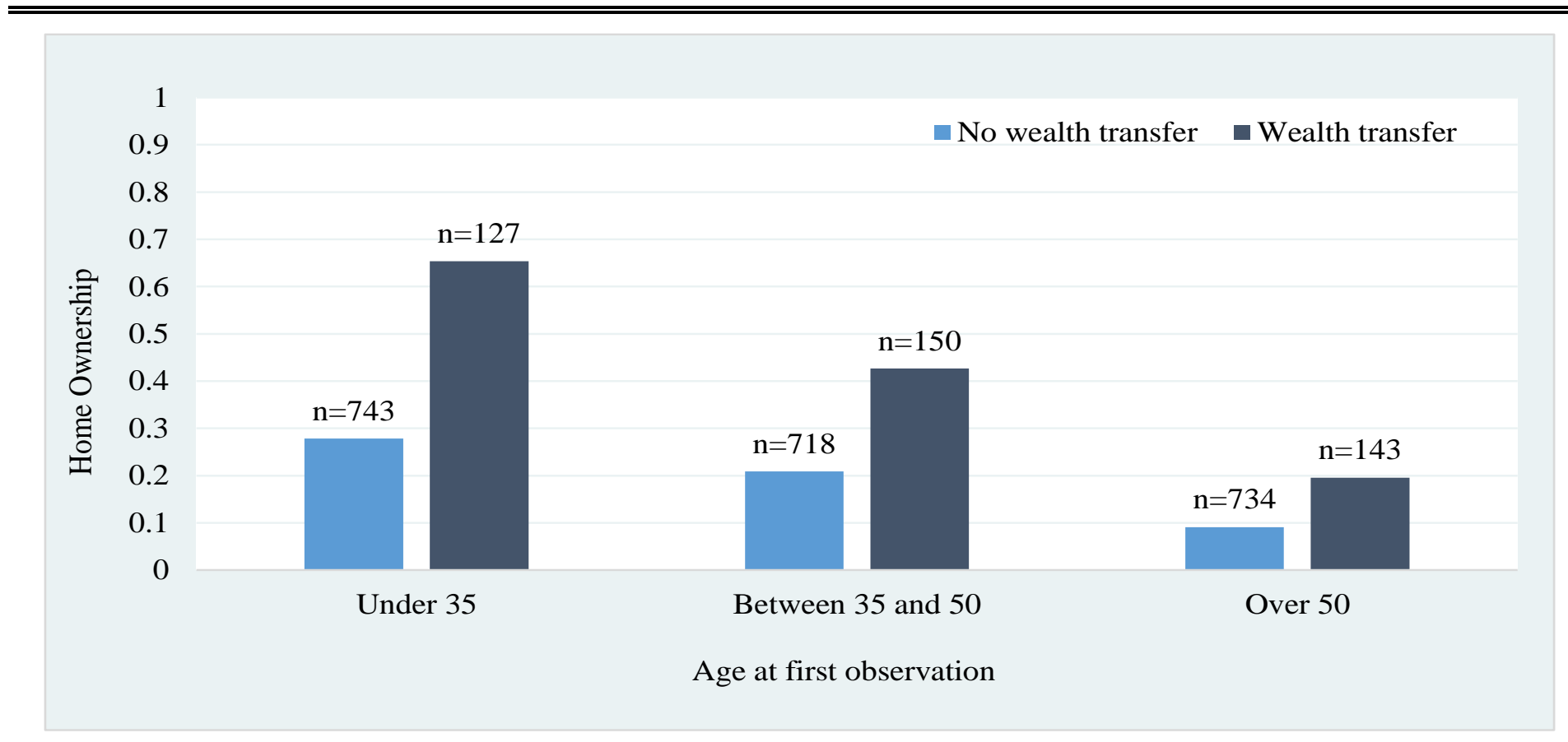


Figure 2. Timing of Wealth Transfers and transition to Home Ownership

For the sample of initial renters who transition to ownership and receive a Wealth Transfer, this image depicts when a household transitions to ownership in relation to when it receives wealth. The $\mathrm{x}$ axis indicates the number of years between receipt of wealth and transition to ownership. $<0$ : wealth received before transition to ownership; >0: wealth received after transition.

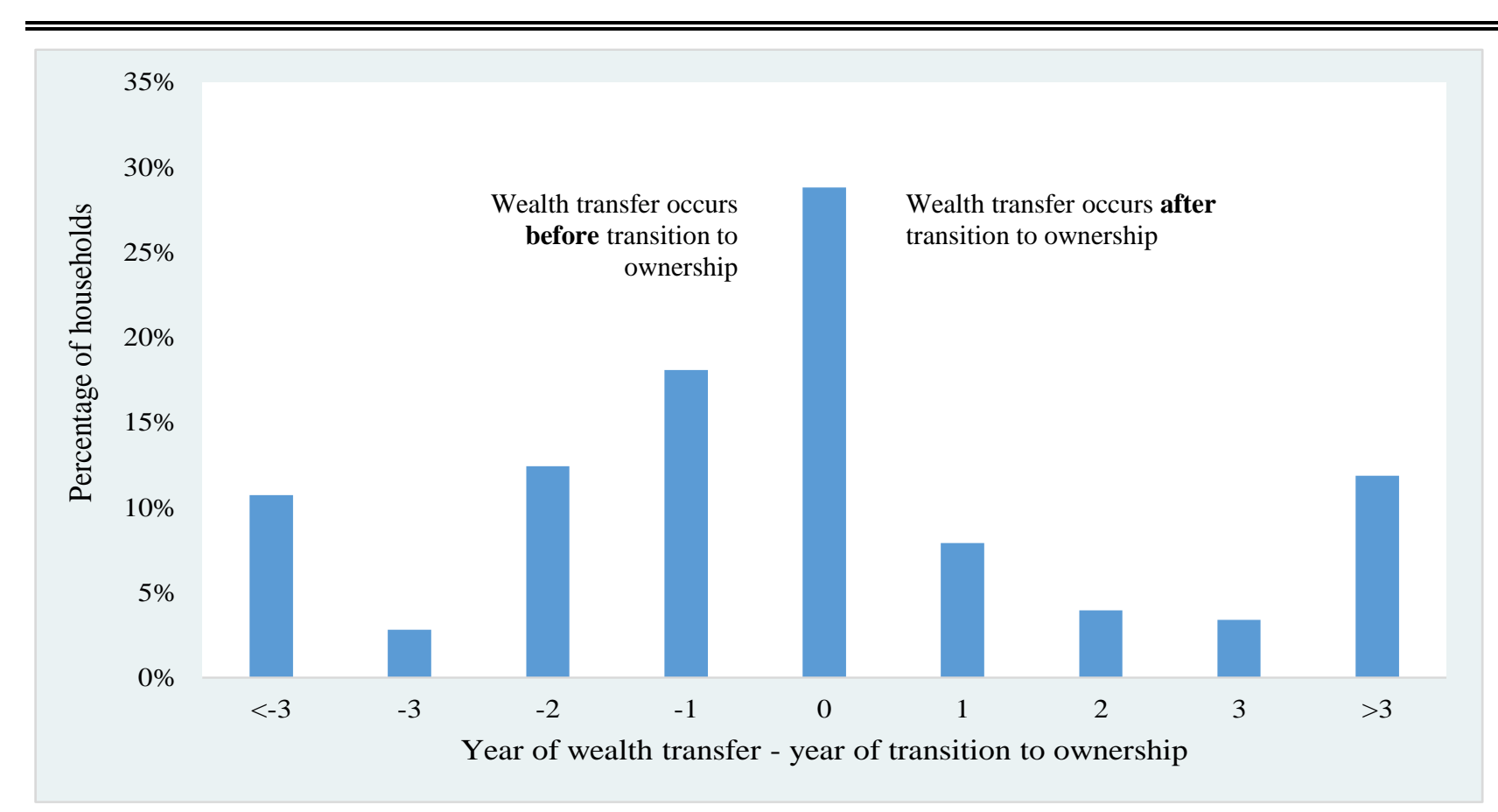


Figure 3: Wealth Transfers and Trading Up

For the sample of initial owners, this figure shows the relationship between receiving a wealth transfer and a household's propensity to move (Panel A), the change in the number of reported rooms (Panel B) and the change in reported neighbourhood satisfaction (Panel C). Numbers above the bar chart indicate sample size. We separate households by age at first observation.

\section{Panel A: Propensity to Move House}

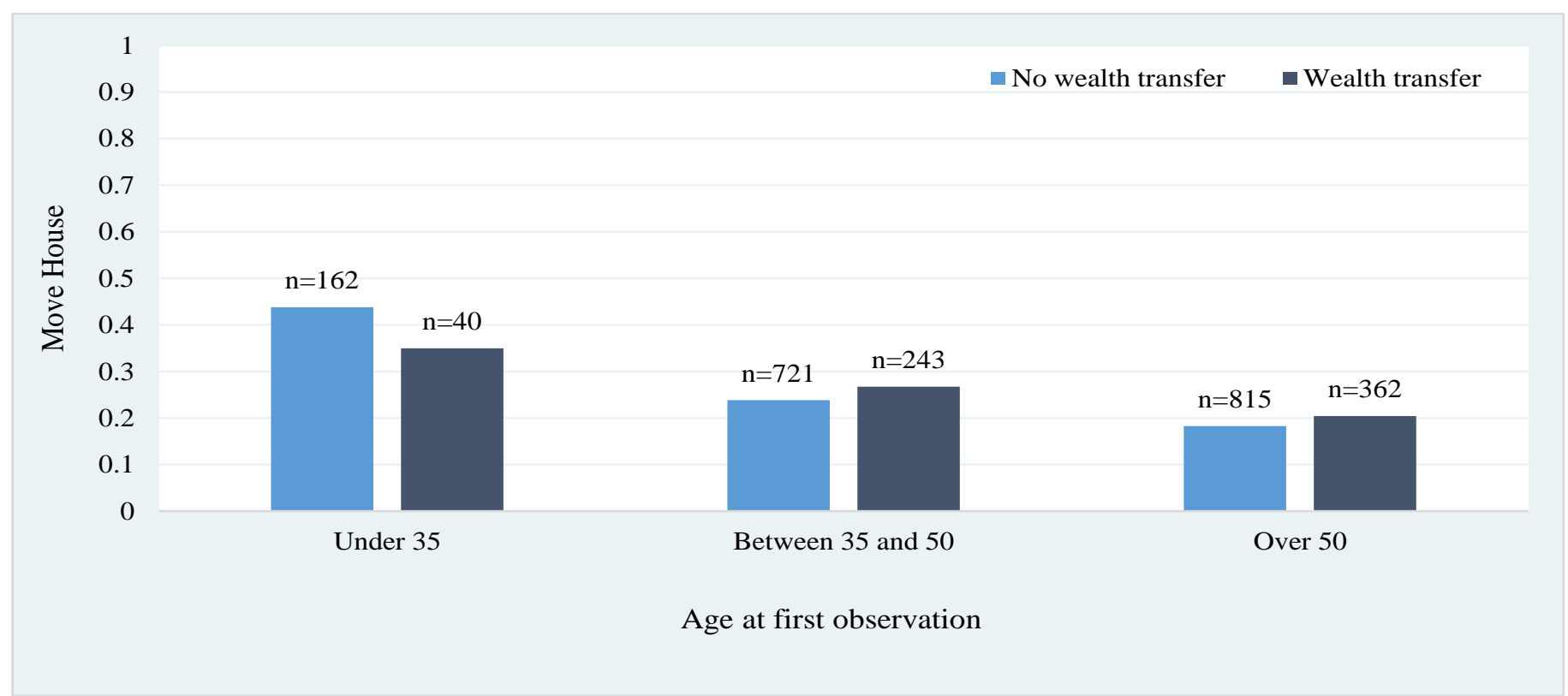


Figure 3 (continued 2 of 3 )

Panel B: Change in the number of rooms (first vs. last observation)

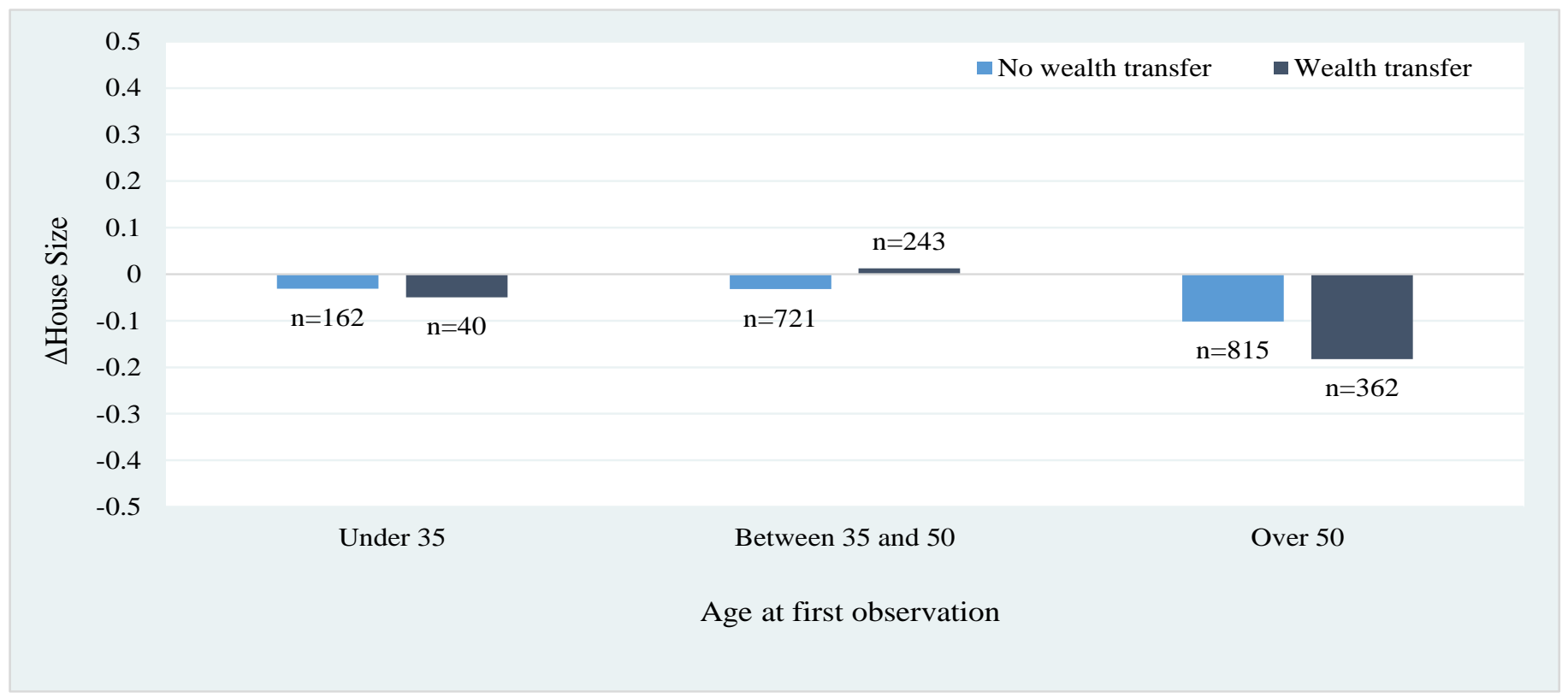


Figure 3 (continued 3 of 3 )

Panel C: Change in satisfaction with neighbourhood (first vs. last observation)

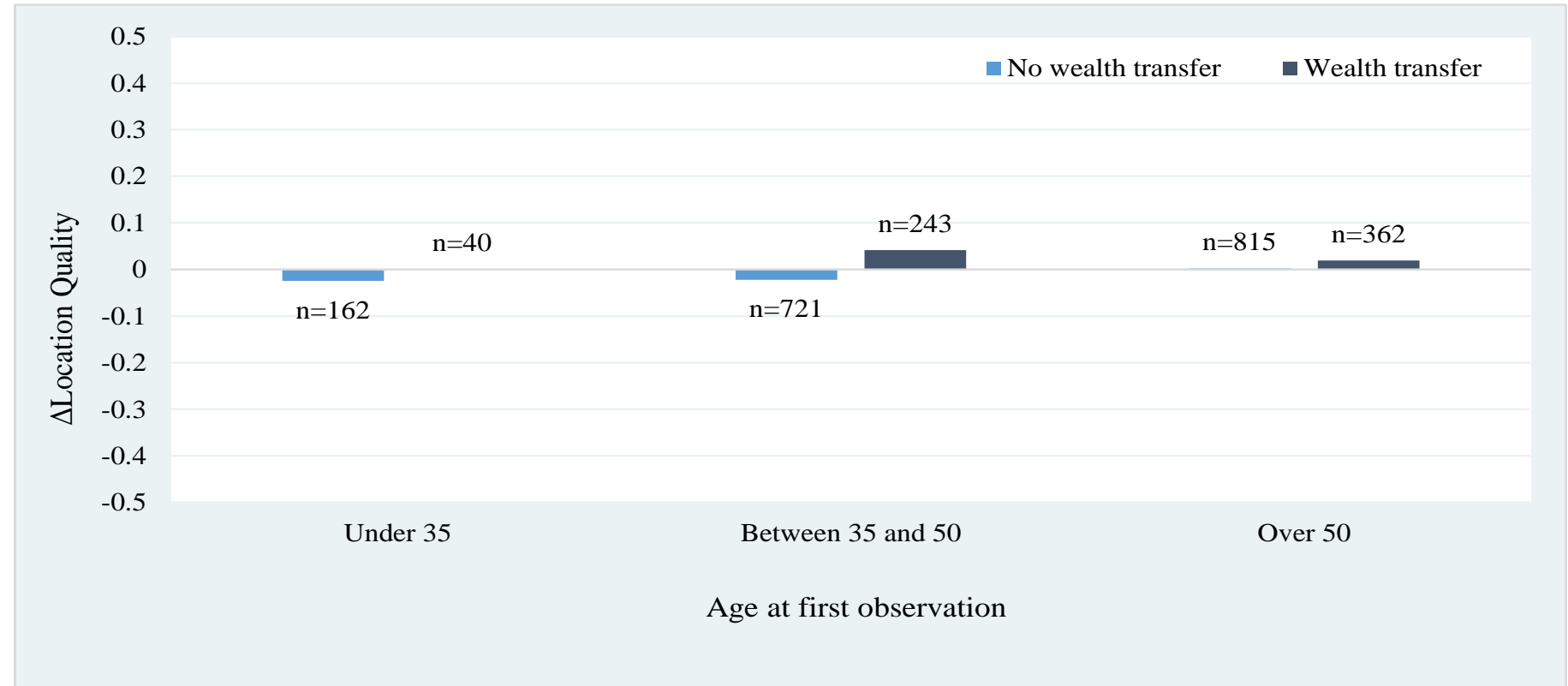


Table 1. Summary statistics

This table shows summary statistics for all variables used in our empirical analysis. Panel A focuses on initial renters. Panel B shows initial owners. ${ }^{*} \mathrm{p}<0.10 \quad * * \mathrm{p}<0.05 \quad * * * \mathrm{p}<0.010$

Panel A: Initial renters

Household receives Wealth Transfer:

Variable Name

mean

sd

p50 N

No $(\mathrm{N}=2195) \quad$ Yes $(\mathrm{N}=420) \quad$ Difference

Dependent Variable:

Home Ownership

0.23

0.42

$0 \quad 2615$

0.19

0.41

$-0.22 * * *$

Explanatory Variables:

$\begin{array}{lllll}\text { Wealth Transfer } & 0.16 & 0.37 & 0 & 2615 \\ \text { Family Death } & 0.84 & 0.37 & 1 & 2615\end{array}$

0.82

0.92

$-0.10 * * *$

Household and Regional Controls:

\begin{tabular}{|c|c|c|c|c|c|c|c|}
\hline Wealthy Parents & 0.35 & 0.48 & 0 & 2615 & 0.33 & 0.49 & $-0.17 * * *$ \\
\hline Age & 45.2 & 15.8 & 42.0 & 2615 & 45.3 & 44.7 & 0.5 \\
\hline Number Children & 0.48 & 0.90 & 0 & 2615 & 0.47 & 0.50 & -0.03 \\
\hline Increase Children & 0.19 & 0.39 & 0 & 2615 & 0.18 & 0.23 & $-0.05 *$ \\
\hline Decrease Children & 0.16 & 0.37 & 0 & 2615 & 0.16 & 0.15 & 0.01 \\
\hline Income & 83,239 & 66,894 & 77,651 & 2615 & 80401 & 98074 & $-17673 * * *$ \\
\hline$\Delta$ Income & 8,437 & 67,964 & 816 & 2615 & 8406 & 8598 & $-192 *$ \\
\hline Education (yrs) & 13.7 & 3.2 & 12 & 2615 & 13.5 & 14.6 & $-1.1 * * *$ \\
\hline Married & 0.53 & 0.50 & 1 & 2615 & 0.52 & 0.57 & -0.05 \\
\hline New Marriage & 0.21 & 0.41 & 0 & 2615 & 0.21 & 0.26 & $-0.06 *$ \\
\hline Divorce & 0.18 & 0.38 & 0 & 2615 & 0.17 & 0.19 & -0.02 \\
\hline Siblings & 0.89 & 0.30 & 1 & 2615 & 0.90 & 0.90 & 0.01 \\
\hline Price/Rent & 34.4 & 2.8 & 34.6 & 2615 & 34.4 & 34.5 & -0.1 \\
\hline$\Delta$ Price $/$ Rent & 3.3 & 3.0 & 2.4 & 2615 & 3.4 & 3.1 & $0.3 *$ \\
\hline Repayment Arrears & 0.12 & 0.33 & 0 & 2615 & 0.05 & 0.13 & $-0.08 * * *$ \\
\hline \# Observations & 8.5 & 2.2 & 9.0 & 2615 & 9.3 & 8.3 & $1.0 * * *$ \\
\hline Intact Home & 0.87 & 0.32 & 1 & 2615 & 0.92 & 0.86 & $0.06 * * *$ \\
\hline \multicolumn{8}{|l|}{ Additional Controls: } \\
\hline Planning Ability & 3.8 & 2.5 & 4.0 & 2179 & 3.5 & 3.9 & $-0.4 * *$ \\
\hline Political Lean & 4.5 & 1.9 & 5.0 & 2179 & 4.6 & 4.5 & 0.2 \\
\hline$\Delta$ Planning Ability & 0.22 & 1.5 & 0 & 2179 & 0.28 & 0.20 & 0.08 \\
\hline$\Delta$ Political Lean & 0.16 & 1.7 & 0 & 2179 & 0.14 & 0.16 & -0.02 \\
\hline
\end{tabular}


Table 1 (continued 2 of 2 )

Panel B: Initial owners

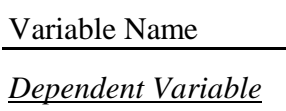

Move House

$\Delta$ Location Quality

$\Delta$ House Size

mean

sd $\mathrm{p} 50$

$\mathrm{N}$

Explanatory Variables:

$\begin{array}{lllll}\text { Wealth Transfer } & 0.28 & 0.45 & 0 & 2343 \\ \text { Family Death } & 0.88 & 0.33 & 1 & 2343\end{array}$

Household and Regional Controls:

\begin{tabular}{|c|c|c|c|c|}
\hline Wealthy Parents & 0.51 & 0.50 & 1 & 2343 \\
\hline Age & 51.9 & 13.3 & 51.0 & 2343 \\
\hline Number Children & 0.82 & 1.12 & 0 & 2343 \\
\hline Increase Children & 0.07 & 0.26 & 0 & 2343 \\
\hline Decrease Children & 0.30 & 0.46 & 0 & 2343 \\
\hline Income & 105,057 & 98,350 & 100,659 & 2343 \\
\hline$\Delta$ Income & $-12,557$ & 88,319 & 0 & 2343 \\
\hline Education (yrs) & 13.8 & 3.3 & 12 & 2343 \\
\hline Married & 0.81 & 0.39 & 1 & 343 \\
\hline New Marriage & 0.10 & 0.30 & 0 & 343 \\
\hline Divorce & 0.18 & 0.39 & 0 & 2343 \\
\hline Siblings & 0.94 & 0.25 & 1 & 2343 \\
\hline Price/Rent & 33.9 & 2.8 & 33.8 & 2343 \\
\hline$\Delta$ Price/Rent & 2.6 & 3.0 & 1.8 & 2343 \\
\hline Intact Home & 0.93 & 0.24 & 1 & 2343 \\
\hline Repayment Arrears & 0.06 & 0.23 & 0 & 2343 \\
\hline \# Observations & 8.59 & 2.28 & 9 & 2343 \\
\hline
\end{tabular}

Additional Controls:

$\begin{array}{lrrrr}\text { Planning Ability } & 3.9 & 2.4 & 4.0 & 2030 \\ \text { Political Lean } & 4.9 & 1.8 & 5.0 & 2030 \\ \Delta \text { Planning Ability } & 0.19 & 1.3 & 0 & 2030 \\ \Delta \text { Political Lean } & 0.14 & 1.7 & 0 & 2030\end{array}$

Household receives Wealth Transfer:

\begin{tabular}{rrr} 
No $(\mathrm{N}=2195)$ & Yes $(\mathrm{N}=420)$ & Difference \\
\hline & & \\
0.23 & 0.24 & -0.01 \\
-0.01 & 0.02 & -0.03 \\
-0.06 & -0.10 & 0.04
\end{tabular}

0.86

$0.90 \quad-0.04 * *$

$\begin{array}{lll}0.47 & 0.63 & -0.16 * * * \\ 51.8 & 52.3 & -0.5 \\ 0.85 & 0.75 & 0.10 \\ 0.08 & 0.06 & 0.02 \\ 0.30 & 0.29 & 0.01\end{array}$

$95,905 \quad 129,150 \quad-33,245 * * *$

$-4,042 \quad-34,972 \quad 30,930 * * *$

$\begin{array}{lll}13.5 & 14.8 & -1.3 * * *\end{array}$

$\begin{array}{lll}0.80 & 0.84 & -0.03\end{array}$

$\begin{array}{lll}0.09 & 0.13 \quad-0.03\end{array}$

$\begin{array}{lll}0.18 & 0.21 & -0.03\end{array}$

$\begin{array}{lll}0.93 & 0.96 & -0.03\end{array}$

$\begin{array}{lll}33.7 & 34.2 & -0.5 * * *\end{array}$

$\begin{array}{lll}2.7 & 2.4 & 0.2\end{array}$

$0.92 \quad 0.94 \quad-0.03 *$

$\begin{array}{lll}0.07 & 0.04 & 0.03 *\end{array}$

$\begin{array}{lll}8.27 & 9.35 & -1.08 * * *\end{array}$

$\begin{array}{rrr}4.0 & 3.7 & 0.3 * * \\ 4.9 & 4.9 & 0.0 \\ 0.22 & 0.14 & 0.07 \\ 0.15 & 0.12 & 0.03\end{array}$


Table 2. Wealth Transfers and Home Ownership: OLS

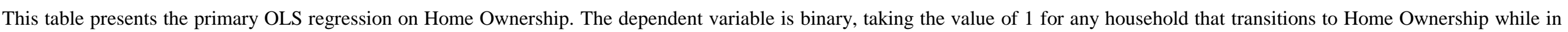

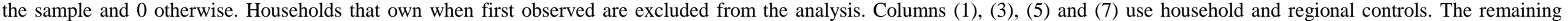

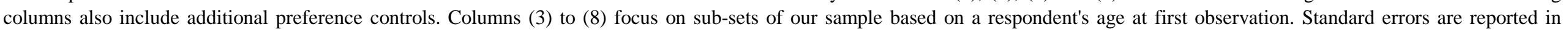
parentheses. ${ }^{*} \mathrm{p}<0.10 * * \mathrm{p}<0.05 \quad * * * \mathrm{p}<0.010$

\begin{tabular}{|c|c|c|c|c|c|c|c|c|}
\hline \multirow[t]{2}{*}{ Sample: } & \multicolumn{2}{|l|}{ Full sample } & \multicolumn{2}{|c|}{ Respondent under 35} & \multicolumn{2}{|c|}{ Respondent between 35 and 50} & \multicolumn{2}{|c|}{ Respondent over 50} \\
\hline & (1) & (2) & (3) & (4) & $(5)$ & (6) & (7) & (8) \\
\hline Wealth Transfer & $\begin{array}{c}0.168 * * * \\
(0.0250)\end{array}$ & $\begin{array}{c}0.168 * * * \\
(0.0282)\end{array}$ & $\begin{array}{c}0.270 * * * \\
(0.0432)\end{array}$ & $\begin{array}{c}0.276^{* * *} \\
(0.0448)\end{array}$ & $\begin{array}{c}0.179 * * * \\
(0.0385)\end{array}$ & $\begin{array}{c}0.175 * * * \\
(0.0441)\end{array}$ & $\begin{array}{c}0.0794 * * \\
(0.0322)\end{array}$ & $\begin{array}{c}0.0721 * \\
(0.0399)\end{array}$ \\
\hline Respondent under 35 & $\begin{array}{c}0.0633^{* *} \\
(0.0280)\end{array}$ & $\begin{array}{c}0.0724 * * \\
(0.0290)\end{array}$ & & & & & & \\
\hline Respondent between 35 and 50 & $\begin{array}{c}0.0163 \\
(0.0136)\end{array}$ & $\begin{array}{c}0.0234 * \\
(0.0130)\end{array}$ & & & & & & \\
\hline Constant & $\begin{array}{c}0.370 * * \\
(0.155)\end{array}$ & $\begin{array}{l}0.317 * \\
(0.160)\end{array}$ & $\begin{array}{l}0.530 * \\
(0.298)\end{array}$ & $\begin{array}{c}0.376 \\
(0.293)\end{array}$ & $\begin{array}{l}0.414^{*} \\
(0.230)\end{array}$ & $\begin{array}{l}0.0546 \\
(0.266)\end{array}$ & $\begin{array}{c}0.281 \\
(0.177)\end{array}$ & $\begin{array}{l}0.434 * \\
(0.233)\end{array}$ \\
\hline Canton and year fixed effects & Yes & Yes & Yes & Yes & Yes & Yes & Yes & Yes \\
\hline Household and regional controls & Yes & Yes & Yes & Yes & Yes & Yes & Yes & Yes \\
\hline Additional controls & No & Yes & No & Yes & No & Yes & No & Yes \\
\hline $\mathrm{N}$ & 2615 & 2179 & 870 & 749 & 868 & 720 & 877 & 710 \\
\hline $\mathrm{R}-\mathrm{Sq}$ & 0.199 & 0.198 & 0.262 & 0.265 & 0.171 & 0.176 & 0.123 & 0.135 \\
\hline Mean dependent variable & 0.23 & 0.25 & 0.33 & 0.37 & 0.24 & 0.28 & 0.11 & 0.13 \\
\hline Method & OLS & OLS & OLS & OLS & OLS & OLS & OLS & OLS \\
\hline
\end{tabular}


Table 3. Wealth Transfers and Home Ownership: IV

This table presents our IV regression for Home Ownership. The primary instrument is Family Death. We make use of zerostage pre-estimation (see Wooldridge 2002). All test statistics are based on the instruments without zero-stage pre-estimation. Standard errors are reported in parentheses. $* \mathrm{p}<0.10 * * \mathrm{p}<0.05 \quad * * * \mathrm{p}<0.010$

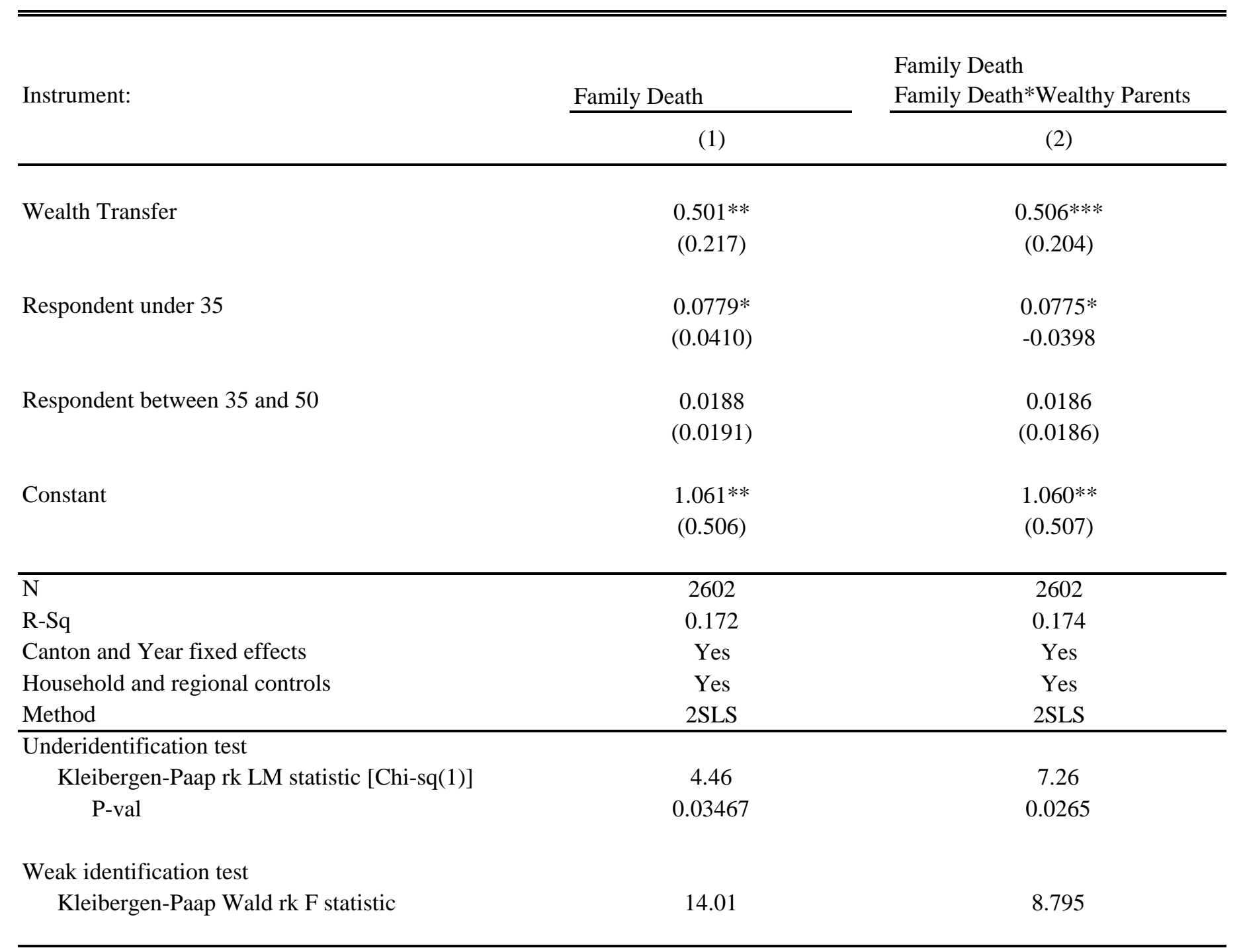


Table 4. Wealth Transfers and Trading Up (OLS)

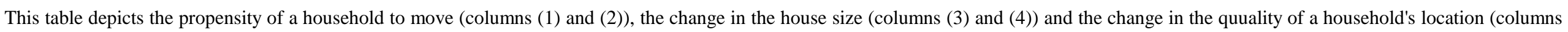

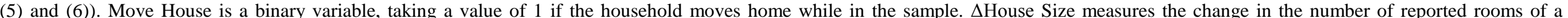

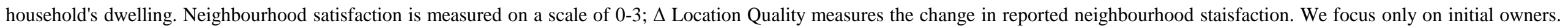
Standard errors are reported in parentheses. * $\mathrm{p}<0.10 \quad * * \mathrm{p}<0.05 \quad * * * \mathrm{p}<0.010$

\begin{tabular}{|c|c|c|c|c|c|c|}
\hline \multirow[t]{2}{*}{ Dependent Variable: } & \multicolumn{2}{|l|}{ Move House } & \multicolumn{2}{|l|}{$\Delta$ House Size } & \multicolumn{2}{|c|}{$\Delta$ Location Quality } \\
\hline & (1) & (2) & (3) & (4) & (5) & (6) \\
\hline Wealth Transfer & $\begin{array}{c}-0.00394 \\
(0.0189)\end{array}$ & $\begin{array}{c}-0.00786 \\
(0.0223)\end{array}$ & $\begin{array}{c}0.0304 \\
(0.0627)\end{array}$ & $\begin{array}{c}0.0313 \\
(0.0686)\end{array}$ & $\begin{array}{c}0.0285 \\
(0.0258)\end{array}$ & $\begin{array}{c}0.0223 \\
(0.0315)\end{array}$ \\
\hline Respondent under 35 & $\begin{array}{l}0.198 * * * \\
(0.0518)\end{array}$ & $\begin{array}{c}0.205^{* * *} \\
(0.0588)\end{array}$ & $\begin{array}{l}-0.213 \\
(0.139)\end{array}$ & $\begin{array}{l}-0.204 \\
(0.136)\end{array}$ & $\begin{array}{l}-0.0143 \\
(0.0760)\end{array}$ & $\begin{array}{c}-0.0498 \\
(0.0806)\end{array}$ \\
\hline Respondent between 35 and 50 & $\begin{array}{c}0.0678 \text { *** } \\
(0.0219)\end{array}$ & $\begin{array}{c}0.0581^{* *} \\
(0.0226)\end{array}$ & $\begin{array}{c}-0.0190 \\
(0.0681)\end{array}$ & $\begin{array}{c}-0.0102 \\
(0.0605)\end{array}$ & $\begin{array}{l}-0.0419 \\
(0.0504)\end{array}$ & $\begin{array}{c}-0.0776 \\
(0.0543)\end{array}$ \\
\hline Constant & $\begin{array}{c}0.0678^{* * * *} \\
(0.0219)\end{array}$ & $\begin{array}{c}0.0581^{* *} \\
(0.0226)\end{array}$ & $\begin{array}{l}-0.336 \\
(0.407)\end{array}$ & $\begin{array}{c}-1.496^{* *} \\
(0.718)\end{array}$ & $\begin{array}{l}-0.0187 \\
(0.235)\end{array}$ & $\begin{array}{l}0.0732 \\
(0.256)\end{array}$ \\
\hline Canton and Year fixed effects & Yes & Yes & Yes & Yes & Yes & Yes \\
\hline Household and regional controls & Yes & Yes & Yes & Yes & Yes & Yes \\
\hline Additional controls & No & Yes & No & Yes & No & Yes \\
\hline $\mathrm{N}$ & 2343 & 2030 & 2343 & 2030 & 2343 & 2030 \\
\hline $\mathrm{R}-\mathrm{Sq}$ & 0.070 & 0.079 & 0.035 & 0.041 & 0.053 & 0.061 \\
\hline Mean dependent variable & 0.23 & 0.24 & -0.08 & -0.09 & 0.00 & -0.01 \\
\hline Method & OLS & OLS & OLS & OLS & OLS & OLS \\
\hline
\end{tabular}




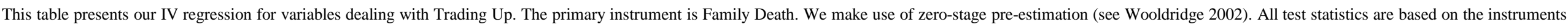

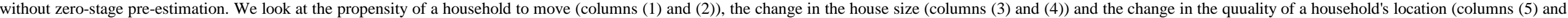

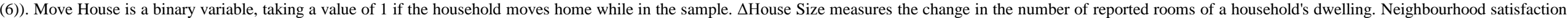
is measured on a scale of $0-3 ; \Delta$ Location Quality measures the change in reported neighbourhood staisfaction. We focus only on initial owners. Standard errors are reported in parentheses. * $\mathrm{p}<0.10 * * \mathrm{p}<0.05 * * * \mathrm{p}<0.010$

\begin{tabular}{|c|c|c|c|c|c|c|}
\hline \multirow{3}{*}{$\begin{array}{l}\text { Dependent variable: } \\
\text { Instrument: }\end{array}$} & \multicolumn{2}{|l|}{ Move House } & \multicolumn{2}{|l|}{$\Delta$ House Size } & \multicolumn{2}{|l|}{$\Delta$ Location Quality } \\
\hline & Family Death & $\begin{array}{l}\text { Family Death } \\
\text { Family Death*Wealthy Parents }\end{array}$ & Family Death & $\begin{array}{l}\text { Family Death } \\
\text { Family Death*Wealthy Parents }\end{array}$ & Family Death & $\begin{array}{l}\text { Family Death } \\
\text { Family Death*Wealthy Parent }\end{array}$ \\
\hline & (1) & (2) & (3) & (4) & (5) & (6) \\
\hline Wealth Transfer & $\begin{array}{l}0.00408 \\
(0.180)\end{array}$ & $\begin{array}{l}0.00635 \\
(0.183)\end{array}$ & $\begin{array}{l}-0.501 \\
(0.387)\end{array}$ & $\begin{array}{l}-0.508 \\
(0.386)\end{array}$ & $\begin{array}{l}0.0803 \\
(0.267)\end{array}$ & $\begin{array}{l}0.0573 \\
(0.266)\end{array}$ \\
\hline Respondent under 35 & $\begin{array}{c}0.170^{* * *} \\
(0.0466)\end{array}$ & $\begin{array}{c}0.170^{* * *} \\
(0.0468)\end{array}$ & $\begin{array}{l}-0.292^{*} \\
(0.151)\end{array}$ & $\begin{array}{l}-0.292^{*} \\
(0.153)\end{array}$ & $\begin{array}{l}-0.00420 \\
(0.0719)\end{array}$ & $\begin{array}{r}-0.00685 \\
(0.0728)\end{array}$ \\
\hline Respondent between 35 and 50 & $\begin{array}{c}0.0808^{* * * *} \\
(0.0258)\end{array}$ & $\begin{array}{c}0.0810 * * * \\
(0.0260)\end{array}$ & $\begin{array}{l}-0.0723 \\
(0.0781)\end{array}$ & $\begin{array}{l}-0.0729 \\
(0.0789)\end{array}$ & $\begin{array}{l}-0.0332 \\
(0.0567)\end{array}$ & $\begin{array}{l}-0.0352 \\
(0.0569)\end{array}$ \\
\hline Constant & $\begin{array}{l}1.346 \\
(1.137)\end{array}$ & $\begin{array}{c}1.344 \\
(1.137)\end{array}$ & $\begin{array}{l}-0.352 \\
(0.390)\end{array}$ & $\begin{array}{l}-0.355 \\
(0.392)\end{array}$ & $\begin{array}{c}0.00501 \\
(0.236)\end{array}$ & $\begin{array}{c}-0.00317 \\
(0.234)\end{array}$ \\
\hline $\bar{N}$ & 2323 & 2323 & 2323 & 2323 & 2323 & 2323 \\
\hline $\mathrm{R}-\mathrm{Sq}$ & 0.098 & 0.098 & 0.017 & 0.016 & 0.025 & 0.025 \\
\hline Canton and Year fixed effects & Yes & Yes & Yes & Yes & Yes & Yes \\
\hline Basic Household and regional controls & Yes & Yes & Yes & Yes & Yes & Yes \\
\hline Method & $2 \mathrm{SLS}$ & 2SLS & 2SLS & 2SLS & 2SLS & $2 \mathrm{SLS}$ \\
\hline \multicolumn{7}{|l|}{ Underidentification test } \\
\hline $\begin{array}{l}\text { Kleibergen-Paap rk LM statistic } \\
\text { [Chi-sq(1)] } \\
\quad \text { P-val }\end{array}$ & $\begin{array}{c}0.07 \\
0.8\end{array}$ & $\begin{array}{c}0.08 \\
0.9\end{array}$ & $\begin{array}{c}0.07 \\
0.8\end{array}$ & $\begin{array}{c}0.08 \\
0.9\end{array}$ & $\begin{array}{c}0.07 \\
0.8\end{array}$ & $\begin{array}{c}0.08 \\
0.9\end{array}$ \\
\hline \multicolumn{7}{|l|}{ Weak identification test } \\
\hline Kleibergen-Paap Wald rk F statistic & 0.2 & 0.05 & 0.2 & 0.05 & 0.2 & 0.05 \\
\hline
\end{tabular}


Online Appendix for:

Liquidity Constraints, Wealth Transfers and Home Ownership

Kristian Blickle and Martin Brown

September 2016 
Appendix 1. Data structure by year of entry

This table showcases the structure of our data. It shows the number of households that are observed for X number of years, based on their year of entry into the sample. We restrict our analysis to households that are observed for at least three years.

\begin{tabular}{|c|c|c|c|c|c|c|c|c|c|c|c|}
\hline \multirow{12}{*}{ 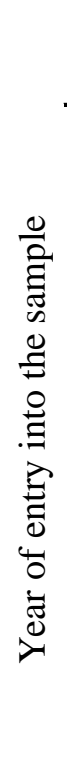 } & & \multicolumn{10}{|c|}{ Number of observations } \\
\hline & & 3 & 4 & 5 & 6 & 7 & 8 & 9 & 10 & 11 & Total \\
\hline & 2002 & 208 & 172 & 190 & 179 & 213 & 111 & 188 & 275 & 1,271 & 2,807 \\
\hline & 2003 & 8 & 8 & 10 & 10 & 7 & 10 & 16 & 38 & & 107 \\
\hline & 2004 & 2 & 6 & 124 & 153 & 141 & 180 & 774 & & & 1,380 \\
\hline & 2005 & 5 & 6 & 15 & 15 & 21 & 63 & & & & 125 \\
\hline & 2006 & 5 & 1 & 8 & 14 & 49 & & & & & 77 \\
\hline & 2007 & 18 & 39 & 31 & 188 & & & & & & 276 \\
\hline & 2008 & 4 & 1 & 77 & & & & & & & 82 \\
\hline & 2009 & 11 & 80 & & & & & & & & 91 \\
\hline & 2010 & 13 & & & & & & & & & 13 \\
\hline & Total & 274 & 313 & 455 & 559 & 431 & 364 & 978 & 313 & 1,271 & 4,958 \\
\hline
\end{tabular}




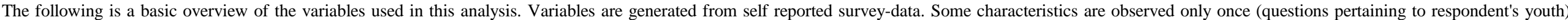

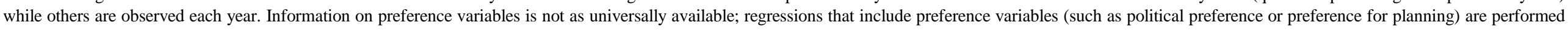
on a slightly smaller subset of the available data.

Variable Name

Definition

Dependent Variables

Home Ownership

Move House

$\Delta$ Location Quality

$\Delta$ House Size

Explanatory Variables:

Wealth Transfer

Family Death

Household and Regional Controls:

Wealthy Parents

Age

Number Children

Increase Children

Decrease Children
A binary variable that takes the value of 1 if a household transitions to ownership while in the sample

A binary variable that takes the value of 1 if a household moves while in the sample

A variable that compares a household's satisfaction with the neighbourhood at the outset and end of the sample period (satisfaction is scaled from $0-3$ and measures satisfaction with noise, pollution and vandalism in an area)

A variable that compares the number of rooms (reported by the household) at the outset and end of the sample period

Binary variable denoting whether the household received a wealth transfer in excess of 50000 CHF during time in the survey. Sources of wealth are family members not living in the household, inheritance and others

This variable (binary) denotes whether the household reported that a "close relative" of the family has passed away while in the sample.

Binary variable denoting whether a household has at least one parent which can be classified as "wealthy" based on the occupation held while the respondent was 15 years of age. Occupations considered: self employed with employees, partner or executive in a firm

Age of primary respondent when first observed in the sample

Number of children the household reported at first observation

Growth in the number of children (positive) while in the sample. This variable is binary, taking on the value of one if the number of children increased.

Decrease in the number of children (positive) while in the sample. This variable is binary, taking on the value of one if the number of children fell. 
Income

$\Delta$ Income

Education (yrs)

Married

New Marriage

Divorce

Siblings

Price/Rent

$\Delta$ Price/Rent

Intact Home

Repayment Arrears

\# Observations

Additional Controls:

Planning Ability

Political Lean

$\Delta$ Planning Ability

$\Delta$ Political Lean
Household's reported labour income at entry into sample. Around 600 households report 0 labour income. These households are recorded as such and not dropped. Dropping them does not change the magnitude of our coefficients in our baseline regressions reported above.

Increase or decrease in household income during time in sample.

Years of primary respondent education

Household comprises two or more people as a civil-union unit reported as: married or living with partner) when first observed

Household goes from an individual unit to a married /civil-union unit during time in survey

Household undergoes a split from a single unit during time in survey. Note: this variable includes: divorced, separated, or widowed

Respondent(s) had siblings while growing up. The variable is binary and takes on a value of 1 if either HH-head (in cases of married households) says yes

Price to rent ratio in the MS region into which a household transitions. For non-transitioning households MS-region of residence is applied. Baseline year is 2003 given dataavailability

Increase in price to rent ratio over household's time in survey

The respondent (at least one respondent in a two respondent household) lived with both mother and father when aged 15. Household considered "intact" if both parents present Binary variable denoting whether a household has reported being behind on payments "frequently" at least once during its time in the survey

The number of times a household is observed in the data

Respondent (one or more respondents in a two person household) above median [5] on a self-reported scale pertaining to "perceived ability to make plans".

Respondent (one or more respondents in a two person household) reports right leaning stance as pertains to the political spectrum (above 5 on a self-reported scale of 1-10).

Change in a household political lean over time.

Change in the household's perceived ability to make plans. 
Appendix 3. Wealth Transfers and Home Ownership (OLS): Longform of Table 2

This table presents the regression shown in Table 2, showing all variables. It depicts the propensity of a household to transition to ownership. The dependent variable is binary, taking the value of one for any household that transitions. Households that own when first observed are excluded from the analysis. Standard errors are reported in parentheses. $* \mathrm{p}<0.10 * * \mathrm{p}<0.05 \quad * * * \mathrm{p}<0.010$

Sample: Full Sample

(1)

$$
0.168 * * *
$$$$
\text { (0.0250) }
$$

0.00644

(0.0251)

0.00500

(0.0228)

$0.0633 * *$

(0.0280)

0.0163

(0.0136)

$0.0813^{* * *} *$

(0.0203)

$0.144 * * *$

(0.0266)

$-0.0198$

(0.0275)

$0.0861 * * *$

(0.0138)

$0.0373 * *$

(0.0145)

0.0000571

(0.00222)

$0.0541 * *$

(0.0227)

$0.0819 * * *$

(0.0249)
(2)

0.168 ***

(0.0282)

0.0187

$-0.00147$

(0.0238)

$0.0724 * *$

(0.0290)

$0.0234 *$

(0.0130)

$0.0968 * * *$

(0.0240)

$0.135^{* * *}$

$-0.000387$

(0.0593)

$0.0952 * * *$

$0.0315 *$

(0.0156)

0.000824

(0.00287)

$0.0674 * *$

(0.0251)

$0.0987 * * *$

(0.0210) 
Appendix 3 (continued 2 of 2 )

Divorce

$-0.0849 * * *$

(0.0284)

$-0.0950 * * *$

(0.0319)

Price/Rent

$-0.0142 * * *$

$-0.0160 * * *$

(0.00417)

(0.00395)

$\Delta$ Price/Rent

$-0.0120 *$

$-0.0125^{*}$

$(0.00681)$

(0.00689)

Intact Home

0.0152

0.0182

(0.0261)

(0.0306)

Repayment Arrears

$-0.0827 * * *$

$-0.0958 * * *$

(0.0268)

(0.0283)

\# Observations

$0.00985 * *$

$0.0125 * * *$

(0.00374)

(0.00429)

Planning Ability

$-0.00178$

(0.00583)

Political Lean

$0.0145 * * *$

$(0.00456)$

$\Delta$ Planning Ability

0.00955

(0.00644)

$\Delta$ Political Lean

$-0.00713$

$(0.00684)$

Constant

$0.370 * *$

$0.317^{*}$

(0.155)

(0.160)

\begin{tabular}{lcc}
\hline Canton and Year fixed effects & Yes & Yes \\
$\mathrm{N}$ & & \\
$\mathrm{R}-\mathrm{Sq}$ & 2615 & 2179 \\
\hline
\end{tabular}


Appendix 4. Wealth Transfers and Home Ownership: Alternative estimation methods

This table depicts the propensity of a household to transition to ownership. We make use of a probit as opposed to a linear probability model in Panel A and radius matching in Panel B. Only the marginal effects for the coefficients of interest are reported for brevity. The dependent variable is binary, taking the value of one for any household that transitions. Households that own when first observed are excluded from the analysis. Standard errors are reported in parentheses. * $\mathrm{p}<0.10 * * \mathrm{p}<0.05 \quad * * * \mathrm{p}<0.010$

=

Panel A: Home Ownership (Probit Analysis)

$(1)$

$\begin{array}{llr}\text { Wealth transfer } & 0.14 * * * & 0.16^{* * * *} \\ & (0.0283) & (0.0306)\end{array}$

\begin{tabular}{lcc}
\hline $\mathrm{N}$ & & 2173 \\
$\mathrm{R}-\mathrm{Sq}$ & 2608 & 0.19 \\
Canton and Year fixed effects & 0.20 & Yes \\
Household and regional controls & Yes & Yes \\
Additional controls & Yes & Yes \\
Method & No & Probit \\
\hline
\end{tabular}


Appendix 4 (continued 2 of 2)

Panel B: Home Ownership (Matching Analysis)

(1) (2)

\begin{tabular}{lcc}
\hline Wealth transfer & $0.224^{* * *}$ & $0.217^{* * *}$ \\
& $(0.0783)$ & $(0.0906)$ \\
& & 2173 \\
\hline $\mathrm{N}$ & 2608 & Yes \\
Canton and Year fixed effects & Yes & Yes \\
Household and regional controls & Yes & Yes \\
Additional controls & No & Radius Matching \\
Method & Radius Matching & \\
\hline
\end{tabular}


Appendix 5. Wealth Transfers and Home Ownership: Alternative Wealth Transfer thresholds

This table depicts the propensity of a household to transition to ownership. We make use linear probability models, as in the main analysis. In panel A we define a wealth transfer as having occurred if a household receives between 10,000 and 50,000 CHF. In panel B we define a wealth transfer as having occurred if a household receives between 100,000 and 200,000 CHF. The dependent variable is binary, taking the value of one for any household that transitions. Households that own when first observed are excluded from the analysis. Standard errors are reported in parentheses. $* \mathrm{p}<0.10 * * \mathrm{p}<0.05 \quad * * * \mathrm{p}<0.010$

Panel A - Home Ownership and low Wealth Transfers

Wealth transfer (10' to 50' CHF)

0.0229

0.0260

(0.0230)

(0.0242)

\begin{tabular}{lcc}
\hline $\mathrm{N}$ & 2615 & 2173 \\
$\mathrm{R}-\mathrm{Sq}$ & 0.18 & 0.19 \\
Canton and Year fixed effects & Yes & Yes \\
Basic household and regional controls & Yes & Yes \\
Additional controls (full set of controls) & No & Yes \\
Method & OLS & OLS \\
\hline
\end{tabular}


Appendix 5 (continued 2 of 2)

Panel B - Home Ownership and high Wealth Transfers

\begin{tabular}{lcc}
\hline & & $0.145^{* * *}$ \\
Wealth transfer (100' to 200' CHF) & $0.141^{* * *}$ & $(0.0459)$ \\
& $(0.0464)$ & 2173 \\
\hline $\mathrm{N}$ & & 0.18 \\
$\mathrm{R}-\mathrm{Sq}$ & 2615 & Yes \\
Canton and Year fixed effects & 0.18 & Yes \\
Basic household and regional controls & Yes & Yes \\
Additional controls (full set of controls) & Yes & OLS \\
Method & OLS & \\
\hline
\end{tabular}




\section{Appendix 6. Wealth Transfers and Home Ownership}

This table depicts the propensity of a household to transition to home ownership. We make use of a linear probability model. We define wealth transfers from family members to have occured (i.e. Wealth Transfer $=1$ ) if at least $10 \%$ of the average house price in a region has been transfered (Panel A). The dependent variable is binary, taking the value of one for any household that transitions. Households that own when first observed are excluded from the analysis. Standard errors are reported in parentheses. $* \mathrm{p}<0.10 \quad * * \mathrm{p}<0.05 \quad * * * \mathrm{p}<0.010$

Panel A - Wealth Transfer at least 10\% of regional prices

(1)

$0.172 * * *$

(0.0270)

$\mathrm{N}$

$\mathrm{R}-\mathrm{Sq}$

Canton and Year fixed effects

Basic household and regional controls

Additional controls (full set of controls)

Method

$\begin{array}{cc}2615 & 2173 \\ 0.20 & 0.19 \\ \text { Yes } & \text { Yes } \\ \text { Yes } & \text { Yes } \\ \text { No } & \text { Yes } \\ \text { OLS } & \text { OLS }\end{array}$

$0.165^{* * *}$

$(0.0294)$

Yes

OLS 
Appendix 6 (continued 2 of 2)

Panel B - 20\% of regional prices

(1)

(2)

Wealth transfer (>20\% of regional house price)

$\begin{array}{lc}0.167 * * * & 0.174 * * * \\ (0.0373) & (0.0358)\end{array}$

\section{$\mathrm{N}$}

$\mathrm{R}-\mathrm{Sq}$

2615

2173

Canton and Year fixed effects

Basic household and regional controls

Additional controls (full set of controls)

Method

0.20

0.19

Yes

Yes

Yes $\quad$ Yes

No Yes

OLS

OLS 
Appendix 7. Wealth Transfers and Home Ownership: Cox hazard rate estimation

This table (Panel A) depicts the propensity of a household to transition to ownership in the context of a hazard-rate analysis. The event in question is the transition to ownership while time represents the time a household spends in the sample. We use all basic controls as before but allow these to vary over time. Our variable of interst takes on a value of 1 once a wealth transfer has occured (and for all periods thereafter). We report hazard rates. Standard errors are reported in parentheses. $* \mathrm{p}<0.10 * * \mathrm{p}<0.05 * * * \mathrm{p}<0.010$ Panel B shows the survival rates for the households who receive vs. those that do not receive wealth.

Panel A - Survival analysis

(1) $(2)$

Wealth transfer

$3.232 * * * \quad 3.3 * * *$

$(0.3448) \quad(0.3571)$

Age: household head is 35 or below when entering sample

$2.481^{* * *} \quad 2.45^{* * *}$

Age: household is between 35 and 50 when entering sample

$1.871^{* * * *} \quad 1.892^{* * * *}$

(0.413) (0.419)

$\mathrm{N}$

Canton and Year fixed effects

Basic Household Controls

Additional household Controls

Method

$\begin{array}{cc}18008 & 18008 \\ \text { Yes } & \text { Yes } \\ \text { Yes } & \text { Yes } \\ \text { No } & \text { Yes } \\ \text { ival Analysis } & \text { Survival An }\end{array}$

18008

Yes

Survival Analysis Survival Analysis 
Appendix 7 (continued 2 of 2)

Panel B - Survival graph

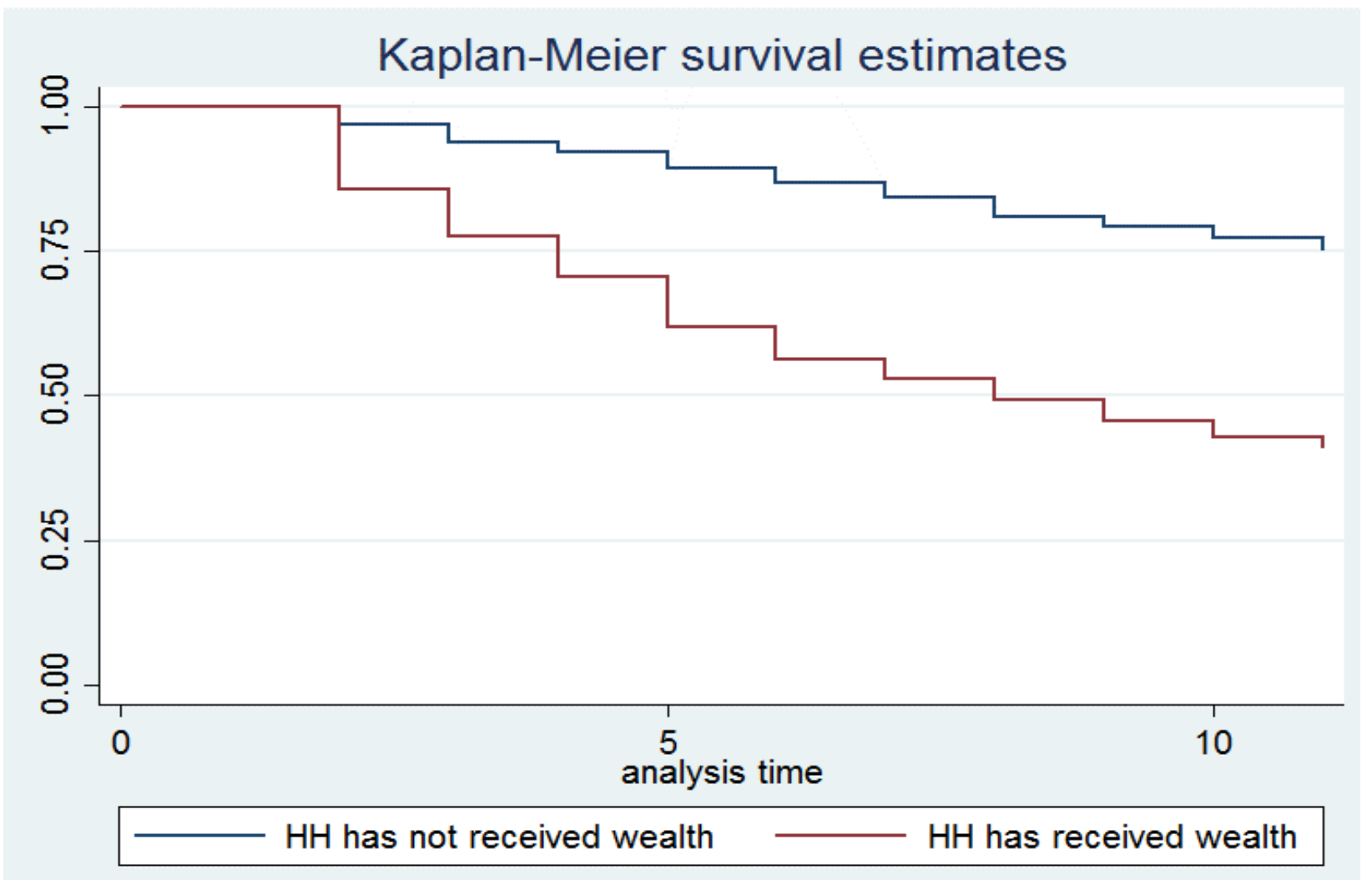


Appendix 8. Socioeconomic characteristics of households by Inheritance

This table shows the difference in socioeconomic characteristics between households who inherit wealth upon the death of a realtive (1) with those that do not inherit upon the death of a relative (2). Column (3) includes households who do not experience the death of a relative.

\begin{tabular}{lrrrr}
\hline \hline & $(1)$ & $(2)$ & $(3)$ & \\
& HH inherits & HH does not inherit & No Family Death & Comparison of (1) vs (2) \\
\cline { 2 - 4 } Wealthy Parents & 0.5 & 0.3 & 0.3 & $0.2 * * *$ \\
Age & 44.9 & 45.8 & 42.9 & -0.9 \\
Number Children & 0.6 & 0.5 & 0.4 & 0.1 \\
Increase Children & 0.2 & 0.2 & 0.1 & 0.04 \\
Decrease Children & 0.2 & 0.2 & 0.1 & 0.0 \\
Income & 105,098 & 70,200 & 81,847 & $24,898 * * *$ \\
Income & 4630.7 & 135.5 & 14854.9 & -2504.8 \\
Education (yrs) & 14.9 & 0.6 & 13.6 & $1.4 * * *$ \\
Married & 0.7 & 0.2 & 0.4 & $0.1 * * *$ \\
New Marriage & 0.2 & 0.1 & 0.2 & 0.0 \\
Divorce & 0.2 & 0.9 & 0.1 & 0.0 \\
Siblings & 0.9 & & 0.9 & 0.00 \\
& & & & \\
\hline
\end{tabular}


Appendix 9. Wealth Transfers and Trading up

This table depicts whether a houshold moves (Panel A), the change in "the number of rooms" (Panel B) as well as the change in "neighbourhood satisfaction" (Panel C). Move House is a binary variable, taking a value of 1 if the household moves home while in the sample. $\Delta$ House Size measures the change in the number of reported rooms of a household's dwelling. Neighbourhood satisfaction is measured on a scale of 0-3; $\Delta$ Location Quality measures the change in reported neighbourhood staisfaction. We focus only on initial owners. Standard errors are reported in parentheses. $* \mathrm{p}<0.10 * * \mathrm{p}<0.05 \quad * * * \mathrm{p}<0.010$

Panel A: MoveHouse

Increase Children

Decrease Children

Income (sclaed 100.000)

$\Delta$ Income (sclaed 100.000)

Education (yrs)

Married
(1)

$$
-0.00394
$$

(0.0189)

$0.0920^{* *}$

(0.0389)

0.0214

(0.0161)

$0.198 * * *$

(0.0518)

$0.0678 * * *$

$-0.0447$

(0.0359)

$-0.00954$

(0.0238)

0.0580

(0.0439)

(2)

$-0.00786$

$(0.0223)$

0.0588

(0.0400)

$0.0311^{*}$

$(0.0154)$

$0.205^{* * * *}$

(0.0588)

$0.0581^{* *}$

(0.0226)

$-0.0519$

(0.0396)

0.0813

(0.0498)

0.00504

(0.0335)

$-0.0022$

(0.0168)

$-0.00948$

(0.0123)

$0.00931 * * *$

0.00838 ***

(0.00293)

$-0.0248$

(0.0271)

0.0508

(0.0457) 
Appendix 9 (continued 2 of 6 )

Divorce

$0.0882 * *$

$0.110 * *$

(0.0400)

(0.0444)

Price/Rent

$-0.000290$

0.000928

(0.00502)

(0.00617)

$\Delta$ Price/Rent

0.00216

0.00155

(0.00445)

(0.00404)

Intact Home

$-0.103 * * *$

$-0.0838 * *$

(0.0303)

(0.0344)

Repayment Arrears

$0.0932 * *$

0.0707

(0.0409)

(0.0435)

\# Observations

$-0.00393$

$-0.00349$

(0.00580)

(0.00606)

Planning Ability

$-0.00827 *$

(0.00434)

Ploitical Lean

0.00224

(0.00579)

$\Delta$ Planning Ability

0.0103

(0.00819)

$\Delta$ Political Lean

$-0.0205^{* * *} *$

(0.00520)

Constant

0.0924

0.357

(0.200)

(0.335)

\begin{tabular}{lcc}
\hline Canton and Year fixed effects & Yes & Yes \\
Method & OLS & OLS \\
$\mathrm{N}$ & 2343 & 2030 \\
$\mathrm{R}-\mathrm{Sq}$ & 0.070 & 0.079 \\
\hline
\end{tabular}


Appendix 9 (continued 3 of 6 )

Panel B: $\Delta$ House Size

Wealth transfer

$\begin{array}{cc}0.0304 & 0.0313 \\ (0.0627) & (0.0686)\end{array}$

Siblings

$-0.175^{*}$

$-0.169$

(0.103)

(0.117)

Wealthy Parents

$-0.0317$

$-0.0639$

(0.0374)

$(0.0388)$

Respondent under 35

$-0.213$

$-0.204$

$(0.139)$

(0.136)

Respondent between 35 and 50

$-0.0190$

$-0.0102$

(0.0681)

(0.0605)

Number Children

$$
0.0901
$$

0.0669

(0.0622)

(0.0742)

Increase Children

$0.485 * * *$

$0.377 * * *$

(0.122)

(0.118)

Decrease Children

$-0.147 * * *$

$-0.135 * *$

(0.0519)

(0.0597)

Income (sclaed 100.000)

$0.109 * * *$

$0.107^{* * *}$

(0.0359)

(0.0369)

$\Delta$ Income (sclaed 100.000)

$0.140 * * *$

$0.151^{* * *}$

(0.0477)

(0.0459)

Education (yrs)

$-0.00681$

$-0.00126$

(0.0106)

(0.0129)

Married

0.0127

0.0183

(0.0686)

(0.0789)

New Marriage

$-0.0695$

0.00888

$(0.160)$

(0.179) 
Appendix 9 (continued 4 of 6 )

Divorce

$\begin{array}{cc}-0.254 * * * & -0.263 * * * \\ (0.0886) & (0.0905)\end{array}$

Price/Rent

0.00449

0.00823

(0.00945)

(0.0106)

$\Delta$ Price/Rent

$-0.0182$

$-0.0124$

$(0.0107)$

(0.0108)

Intact Home

0.238

$0.382 * *$

(0.168)

(0.182)

Repayment Arrears

0.0322

0.0976

(0.131)

(0.147)

\# Observations

$-0.00285$

$-0.00121$

$(0.00955)$

$(0.00948)$

Planning Ability

0.00318

(0.0114)

Ploitical Lean

0.000305

(0.0140)

$\Delta$ Planning Ability

$-0.0121$

(0.0149)

$\Delta$ Political Lean

0.0133

(0.0142)

Constant

$-0.336$

$-1.496 * *$

(0.407)

(0.718)

\begin{tabular}{lcc}
\hline Canton and Year fixed effects & Yes & Yes \\
Method & OLS & OLS \\
$\mathrm{N}$ & 2343 & 2030 \\
$\mathrm{R}-\mathrm{Sq}$ & 0.053 & 0.061 \\
\hline
\end{tabular}


Appendix 9 (continued 5 of 6 )

Panel C: $\Delta$ Location Quality

(1)

(2)

Wealth transfer

0.0285

(0.0258)

0.0223

(0.0315)

Siblings

$-0.0663$

$-0.0827$

(0.0617)

(0.0632)

Wealthy Parents

0.00343

(0.0307)

0.00104

(0.0334)

Respondent under 35

$-0.0143$

(0.0760)

$-0.0498$

(0.0806)

Respondent between 35 and 50

$-0.0419$

(0.0504)

0.0337

(0.0539)

$-0.0744$

(0.0707)

Increase Children

0.0264

(0.0490)

0.0105

(0.0203)

0.0189

(0.0155)

$-0.00543$

(0.00466)

$-0.00802$

(0.0393)

$-0.0178$

(0.0854)
$-0.0776$

(0.0543)

0.0880

(0.0621)

$-0.0615$

(0.0688)

$-0.0117$

(0.0608)

$-0.0086$

(0.0214)

0.059

(0.0192)

$-0.00554$

(0.00487)

$-0.00996$

(0.0461)

0.0218

(0.0903) 
Appendix 9 (continued 6 of 6 )

Divorce

0.0112

(0.0376)

0.00286

(0.00707)

0.00723

(0.00995)

$-0.0281$

(0.0594)

$-0.0933$

(0.0607)

0.00769

(0.00737)

Planning Ability

Ploitical Lean

$\Delta$ Planning Ability

$\Delta$ Political Lean

$-0.0187$

(0.235)

Constant
$-0.0156$

(0.0436)

0.00586

(0.00793)

0.00656

(0.0108)

0.00375

(0.0524)

$-0.0679$

(0.0602)

0.00961

(0.00696)

$-0.0144 * *$

(0.00699)

$-0.0188 *$

(0.0109)

$-0.00473$

(0.0143)

0.00595

(0.0105)

Yes

OLS

Yes

Canton and Year fixed effects

Method

$\mathrm{N}$

2343

OLS

0.035

$\mathrm{R}-\mathrm{Sq}$

0.0732

(0.256) 
Appendix 10. Family Death and Wealth Transfers (IV first stage)

This table depicts the first stage of the IV regression in table 3. We showcase the instruments, without zero stage preestimation in Columns (1) and (2). Column (3) showcases the pre-estimated instrument for illustration purposes (see Wooldridge (2002)).

\begin{tabular}{|c|c|c|c|}
\hline \multirow[t]{2}{*}{ Method: } & \multicolumn{2}{|l|}{ Ordinary 2SIS } & \multirow{2}{*}{$\begin{array}{l}\text { Pre-estimated instrumen } \\
\text { using death in the family }\end{array}$} \\
\hline & (1) & (2) & \\
\hline \multirow[t]{2}{*}{ FamilyDeath } & $0.0555 * * *$ & $0.0473 * * *$ & \\
\hline & $(0.0137)$ & $(0.0148)$ & \\
\hline Family Death $*$ wealthy parents & & $\begin{array}{c}0.0288 \\
(0.0334)\end{array}$ & \\
\hline Pre-estimated Family Death & & & $\begin{array}{c}1.008 * * * \\
(0.164)\end{array}$ \\
\hline Respondent under 35 & $\begin{array}{c}-0.0706^{* * * *} \\
(0.0202)\end{array}$ & $\begin{array}{c}-0.0710^{* * *} \\
(0.0202)\end{array}$ & $\begin{array}{c}0.000115 \\
(0.0264)\end{array}$ \\
\hline Respondent between 35 and 50 & $\begin{array}{c}-0.0293 * \\
(0.0170)\end{array}$ & $\begin{array}{c}-0.0296 * \\
(0.0169)\end{array}$ & $\begin{array}{c}-0.0000863 \\
(0.0225)\end{array}$ \\
\hline Constant & $\begin{array}{l}-0.237 \\
(0.289)\end{array}$ & $\begin{array}{l}-0.230 \\
(0.290)\end{array}$ & $\begin{array}{l}0.0161 \\
(0.309)\end{array}$ \\
\hline Canton and Year fixed effects & Yes & Yes & Yes \\
\hline Household and Regional Controls & Yes & Yes & Yes \\
\hline $\mathrm{N}$ & 2534 & 2534 & 2534 \\
\hline $\mathrm{R}-\mathrm{Sq}$ & 0.122 & 0.122 & 0.128 \\
\hline
\end{tabular}

